\title{
Microbial processes during deposition and diagenesis of Banded Iron Formations
}

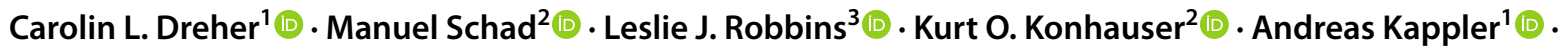 \\ Prachi Joshi ${ }^{1}$ (D)
}

Received: 22 April 2021 / Accepted: 22 November 2021 / Published online: 8 December 2021

(c) The Author(s) 2021

\begin{abstract}
Banded Iron Formations (BIFs) are marine chemical sediments consisting of alternating iron (Fe)-rich and silica ( $\mathrm{Si}$ )-rich bands which were deposited throughout much of the Precambrian era. BIFs represent important proxies for the geochemical composition of Precambrian seawater and provide evidence for early microbial life. Iron present in BIFs was likely precipitated in the form of $\mathrm{Fe}^{3+}(\mathrm{Fe}(\mathrm{III}))$ minerals, such as ferrihydrite $\left(\mathrm{Fe}(\mathrm{OH})_{3}\right)$, either through the metabolic activity of anoxygenic photoautotrophic $\mathrm{Fe}^{2+}(\mathrm{Fe}$ (II))-oxidizing bacteria (photoferrotrophs), by microaerophilic bacteria, or by the oxidation of dissolved $\mathrm{Fe}(\mathrm{II})$ by $\mathrm{O}_{2}$ produced by early cyanobacteria. However, in addition to oxidized $\mathrm{Fe}$-bearing minerals such as hematite $\left(\mathrm{Fe}_{2}^{\mathrm{III}} \mathrm{O}_{3}\right.$ ), (partially) reduced minerals such as magnetite $\left(\mathrm{Fe}^{\mathrm{II}} \mathrm{Fe}_{2}{ }_{2} \mathrm{O}_{4}\right)$ and siderite $\left(\mathrm{Fe}^{\mathrm{II}} \mathrm{CO}_{3}\right)$ are found in BIFs as well. The presence of reduced Fe in BIFs has been suggested to reflect the reduction of primary $\mathrm{Fe}(\mathrm{III})$ minerals by dissimilatory $\mathrm{Fe}(\mathrm{III})$-reducing bacteria, or by metamorphic (high pressure and temperature) reactions occurring in presence of buried organic matter. Here, we present the current understanding of the role of Fe-metabolizing bacteria in the deposition of BIFs, as well as competing hypotheses that favor an abiotic model for BIF deposition. We also discuss the potential abiotic and microbial reduction of Fe(III) in BIFs after deposition. Further, we review the availability of essential nutrients (e.g. P and $\mathrm{Ni}$ ) and their implications on early Earth biogeochemistry. Overall, the combined results of various ancient seawater analogue experiments aimed at assessing microbial iron cycling pathways, coupled with the analysis of the BIF rock record, point towards a strong biotic influence during BIF genesis.
\end{abstract}

Keywords Banded Iron Formations (BIF), iron redox processes $\cdot$ Microbial iron cycling $\cdot$ Nutrients

\section{Introduction}

Precambrian Banded Iron Formations (BIFs) (Fig. 1) are marine chemical sediments consisting of alternating iron oxide-rich and silica-rich bands (Trendall and Blockley 1970). BIFs can be found as massive iron ore deposits in Australia, South Africa, Canada, China, Brazil, Ukraine, and

Handling Editor: Jan-Peter Duda.

Prachi Joshi

prachi.joshi@uni-tuebingen.de

1 Geomicrobiology, Center for Applied Geosciences, University of Tuebingen, Tuebingen, Germany

2 Department of Earth and Atmospheric Sciences, University of Alberta, Edmonton, AB, Canada

3 Department of Geology, University of Regina, Regina, SK, Canada a number of other locations, with occurences noted on every continent (Bekker et al. 2014; Ernst and Bau 2021; Konhauser et al. 2017). For example, the Hamersley Group in Western Australia extends over $\sim 10^{5} \mathrm{~km}^{2}$, and contains more than $10^{13}$ tons of iron (Beukes 1984; Trendall 2002). BIFs may be divided into two broad classes: Algoma-type BIFs that are associated with volcanic arc settings and Superiortype BIFs which were deposited on passive margins (see Bekker et al. 2014 and Konhauser et al. 2017 for reviews). Primarily, BIFs were formed between 3.8 and $1.85 \mathrm{Ga}$, with extensive Superior-type BIFs thought to have mainly been deposited on continental shelves and slopes at depths of less than $400 \mathrm{~m}$ (Trendall 2002), and smaller formations being deposited in the deep ocean (Krapež et al. 2003). Peak BIF deposition has been constrained to the Neoarchean and early Paleoproterozoic (Beukes 1984; Klein 2005; Konhauser et al. 2017; Trendall 2002), shortly preceding the Great Oxidaiton Event (GOE). 


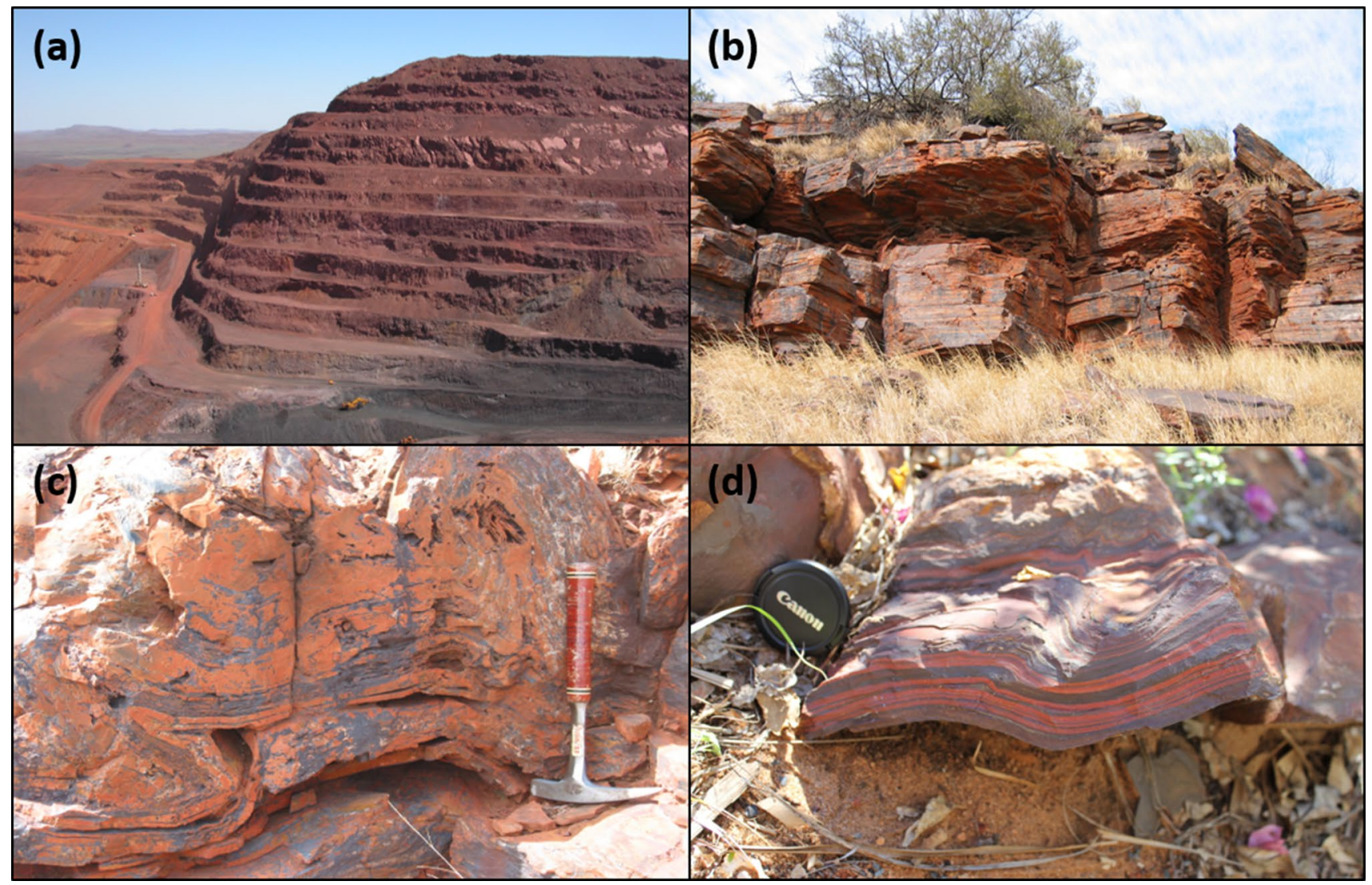

Fig. 1 Photographs of Banded Iron Formations (BIFs); a view of a mine at the southern ridge of the Tom Price BIFs, Western Australia (provided by Mark Barley); b BIF formation in Gamohaan Hill near Kuruman, Northern Cape Province, South Africa; (c) close-up of (b),

BIFs are of great interest as they reflect the (bio)geochemistry of the oceans in which they were deposited. In addition to acting as a proxy for paleomarine chemistry, BIFs also contain evidence of the first significant rise in atmospheric oxygen during the GOE between 2.45 and $2.32 \mathrm{Ga}$ (Bekker et al. 2004; Buick 2008; Farquhar et al. 2011; Konhauser 2011; Pavlov and Kasting 2002; Rye and Holland 1998). Critical to using the BIF record to interpret early Earth conditions is an understanding of formation pathways: were BIFs formed abiotically or through the activity of microorganisms? Evidence of microbial influence on BIF deposition would indicate conditions favorable to life, specifically nutrient-rich oceans (Tyrrell 1999; Zahnle et al. 2006; Zerkle 2005) with circumneutral pH values (Cloud 1965, 1973). On the other hand, if BIF deposition and diagenesis were primarily abiotic processes, Precambrian oceans could have had more alkaline pH values (Beukes and Gutzmer 2008; Tosca et al. 2016) and may have been nutrient-poor (Bjerrum and Canfield 2002).

Here, we review potential pathways for BIF deposition with a particular focus on the role of microorganisms and showing centimeter-thick alternating wavy bands of iron-rich and silica-rich bands; (d) alternating millimeter-thick bands of a Hamersley Group BIF sample, Western Australia (provided by Jan-Peter Duda)

the subsequent post-depositional alteration of iron minerals within BIFs via microbial activity. Then, we review examples of elemental cycling linked to the microbial Fe cycling during BIF deposition, specifically the macronutrient phosphorus and the trace element nickel. We close this review by suggesting potential future research directions that may aid in resolving ongoing controversies regarding the biological role in BIF deposition.

\section{Mineralogy of Banded Iron Formations (BIFs)}

Banded Iron Formations (BIF) consist of alternating bands characterized by high iron oxide $(20-40 \%)$ and high silica (40-60\%) content (Bekker et al. 2014; Beukes 1984; Klein 2005; Konhauser et al. 2017; Trendall 2002). While the silica-rich layers are mostly composed of bedded chert (Rasmussen et al. 2017), the iron oxide-rich layers contain a wide range of iron-bearing minerals with an overall $\mathrm{Fe}$ oxidation state of 2.4 (Klein and Beukes 1992). The mineralogy observed in BIFs today is comprised of magnetite 
$\left(\mathrm{Fe}^{\mathrm{II}} \mathrm{Fe}_{2}{ }_{2} \mathrm{O}_{4}\right)$, hematite $\left(\mathrm{Fe}_{2} \mathrm{O}_{3}\right)$, siderite $\left(\mathrm{FeCO}_{3}\right)$ and other iron carbonates, $\mathrm{Fe}(\mathrm{II} / \mathrm{III})$-silicates, and chert, among others (Bekker et al. 2014; Klein 2005). It is generally recognized that the current mineralogy is the result of diagenetic and metamorphic overprinting of the primary minerals deposited on the seafloor. Ferric oxyhydroxides (e.g. ferrihydrite, $\mathrm{Fe}(\mathrm{OH})_{3}$ ), iron silicates (e.g. greenalite, $\left.\mathrm{Fe}_{3} \mathrm{Si}_{2} \mathrm{O}_{5}(\mathrm{OH})_{4}\right)$ ), $\mathrm{Fe}(\mathrm{III})$-silica gels, and iron carbonates (e.g., siderite, $\mathrm{FeCO}_{3}$ ) have each been hypothesized as the primary mineral phases that were precipitated in the water column and deposited on the seafloor depending on whether a biological or abiotic formation pathway is assumed (Alibert 2016; Dimroth and Chauvel 1973; Halevy et al. 2017; Han 1966, 1978; Johnson et al. 2018; Klein 2005; Percak-Dennett et al. 2011; Perry et al. 1973; Rasmussen et al., 2014, 2015a, b; Sun et al. 2015; Wu et al. 2012; Zegeye et al. 2012).

\section{Atmospheric and marine conditions during BIF deposition}

The atmospheric and oceanic chemical conditions in the Precambrian were substantially different from the modern systems of today. Oxygen concentrations in the atmosphere and global oceans were negligible (Hardisty et al. 2014; Holland 2002; Olson et al. 2013; Pavlov and Kasting 2002). There was no ozone layer in the atmosphere prior to the GOE, resulting in UV radiation penetrating the top layers of the ocean (Bekker et al. 2004; Catling and Zahnle 2020; Konhauser et al. 2017; Lyons et al. 2014). Exceptions to the low oxygen concentrations in the oceans were coastal regions with oxygen produced by cyanobacteria, with assumed maximum oxygen concentrations varying between $5 \mu \mathrm{M}$ and $100 \mu \mathrm{M}$ (Czaja et al. 2012; Kasting 1992; Kendall et al. 2010; Planavsky et al. 2010). Geochemical models predict that Archean oxygen oases were characterized by oxygen concentrations on the order of $10 \mu \mathrm{M}$ (Olson et al. 2013).

Geochemical processes in the marine environment were dominated by the complex interplay of the iron, silicon, and carbon cycles. The absence of silica-precipitating microorganisms allowed dissolved silica to accumulate to concentrations that approached saturation with respect to amorphous silica (0.67-2.2 mM) (Maliva et al. 2005; Siever 1992). Furthermore, the overall low oxygen concentrations in environments distal from cyanobacterial mats allowed the buildup of high concentrations of dissolved Fe(II) (0.02-0.5 mM) (Holland 1973; Morris 1993) sourced from hydrothermally derived fluids (Bau and Möller 1993; Hamade et al. 2003; Jacobsen and Pimentel-Klose 1988). This dissolved Fe(II) was potentially transported either by advection (current driven upwelling of deep waters onto continental shelves), with $\mathrm{Fe}(\mathrm{II})$ at depth supplied by mid ocean ridge systems
(Holland 1973; Konhauser et al. 2007; Morris and Horwitz 1983), or by direct transport into the photic zone by hydrothermal plumes emanating from shallow seamount systems (Isley 1995; Isley and Abbott 1999).

\section{Deposition: primary iron mineral precipitation}

The deposition pathways of BIFs are highly debated. For the precipitation of these alternating iron oxide-rich and silicarich layers, high concentrations of dissolved $\mathrm{Fe}(\mathrm{II})$ in anoxic sea water had to be oxidized to dissolved $\mathrm{Fe}$ (III) and precipitated as $\mathrm{Fe}$ (III) minerals. The oxidation and subsequent precipitation processes have been suggested to occur purely abiotically by some studies, while other studies have argued that microorganisms are directly involved in the oxidation of $\mathrm{Fe}$ (II) and subsequent $\mathrm{Fe}$ (III) mineral precipitation. In principle, biotic and abiotic $\mathrm{Fe}$ minerals differ in chemical composition, particle size, and density (Posth et al. 2014), surface properties (Moon and Peacock 2012), and adsorptive behavior towards nutrients and trace metals (Sundman et al. 2016; Yan et al. 2016). These characteristics may be used to differentiate between the origin of freshly synthesized $\mathrm{Fe}$ minerals; however, since there are no primary Fe(III) minerals preserved that may be examined directly, it is difficult to reconstruct the origin and properties of the primary minerals precipitated from the water column. We discuss below the different chemical and biological hypotheses for BIF mineral formation based on evidence from field observations and laboratory experiments conducted under conditions representative of the early Earth.

\section{Abiotic deposition mechanisms}

Based on the iron silicates present in BIFs today, some studies have argued that the origin of the primary minerals in BIFs was purely abiotic. Harder $(1976,1978)$ observed that nontronite or chamosite, two iron silicates observed in iron-rich formations, could be abiotically formed during anoxic, low-temperature synthesis of poorly crystalline $\mathrm{Fe}(\mathrm{III})$ oxyhydroxides from dissolved $\mathrm{Fe}(\mathrm{II})$ in the presence of silica. Harder $(1976,1978)$ and Konhauser et al. (2007) supported the formation of Fe-silicates in anoxic, non-sulfidic media with high dissolved $\mathrm{Fe}(\mathrm{II})$ and silica concentrations. Amongst the abiotic pathways, one of the proposed hypotheses suggests that $\mathrm{Fe}$ (II/III) silicates, particularly greenalite $\left(\left(\mathrm{Fe}^{\mathrm{II}}, \mathrm{Fe}^{\mathrm{III}}\right)_{2-3} \mathrm{Si}_{2} \mathrm{O}_{5} \mathrm{OH}_{4}\right)$, was the main primary iron mineral and that it was deposited as nanometer-sized mud particles or loose flocs due to co-nucleation of $\mathrm{Fe}$ (II) and silica (Rasmussen et al. 2013, 2015b, 2019a). According to this hypothesis, current BIF 
mineralogy would, therefore, be explained by diagenetic, metamorphic, or weathering overprinting (Rasmussen et al. 2019b). One limitation of this pathway is the high $\mathrm{pH}$ value (7.5-8) necessary for the formation of Fe silicates (Beukes and Gutzmer 2008; Tosca et al. 2016), which is at odds with the assumed slightly acidic to circumneutral $\mathrm{pH}$ of the ocean at that time (Halevy et al. 2017; KrissansenTotton et al. 2018). Further, it has been shown that secondary oxidation of Fe-silicates, either through percolating oxidizing fluids or weathering, is not able to oxidize sufficient amounts of $\mathrm{Fe}$ (II) necessary to explain all the $\mathrm{Fe}$ (III) in BIFs on reasonable time scales (Robbins et al. 2019).

A second prevalent hypothesis concerning the abiotic formation of BIFs is the photochemical oxidation of dissolved Fe(II) (Fig. 2:1). Due to the lack of an ozone layer in the atmosphere, solar UV radiation was not attenuated. Therefore, dissolved $\mathrm{Fe}(\mathrm{II})$ in the photic zone might have adsorbed UV light, at wavelengths from 200 to $400 \mathrm{~nm}$, resulting in the photochemical oxidation of $\sim 0.07$ atoms of dissolved $\mathrm{Fe}(\mathrm{II})$ per photon (Nie et al. 2017) and the formation of $\mathrm{Fe}(\mathrm{III})$

(1) (Braterman et al. 1983; Cairns-Smith 1978)

$$
2 \mathrm{Fe}^{2+}(\mathrm{aq})+2 \mathrm{H}^{+}+h v \rightarrow 2 \mathrm{Fe}^{3+}(\mathrm{aq})+2 \mathrm{H}_{2} \uparrow
$$

However, the photooxidation pathway has been challenged by experimental studies examining the effect of aqueous chemistry on UV photochemical oxidation. (Konhauser et al. (2007) observed experimentally that at high dissolved silica and bicarbonate concentrations, the photooxidation of $\mathrm{Fe}(\mathrm{II})$ by UV light was substantially inhibited. This inhibition would suggest that photochemical oxidation, compared to other deposition pathways, only played a minor role in BIF deposition.

\section{Biotic deposition mechanisms}

The majority of past work looking at biological pathways of BIF formation has focused on the role of cyanobacteria (Fig. 2:2). Fe(III) has been hypothesized to be formed via the chemical oxidation of dissolved $\mathrm{Fe}$ (II) by oxygen produced by cyanobacteria under circumneutral $\mathrm{pH}$ conditions (Cloud 1965, 1973; Konhauser et al. 2007) and minerals such as ferrihydrite $\left(\mathrm{Fe}(\mathrm{OH})_{3}\right)$ are presumed to have been the dominant primary mineral. Once free oxygen became available in the ocean, other microorganisms, such as neutrophilic microaerophilic $\mathrm{Fe}(\mathrm{II})$-oxidizers (Fig. 2:3), may have evolved and further contributed

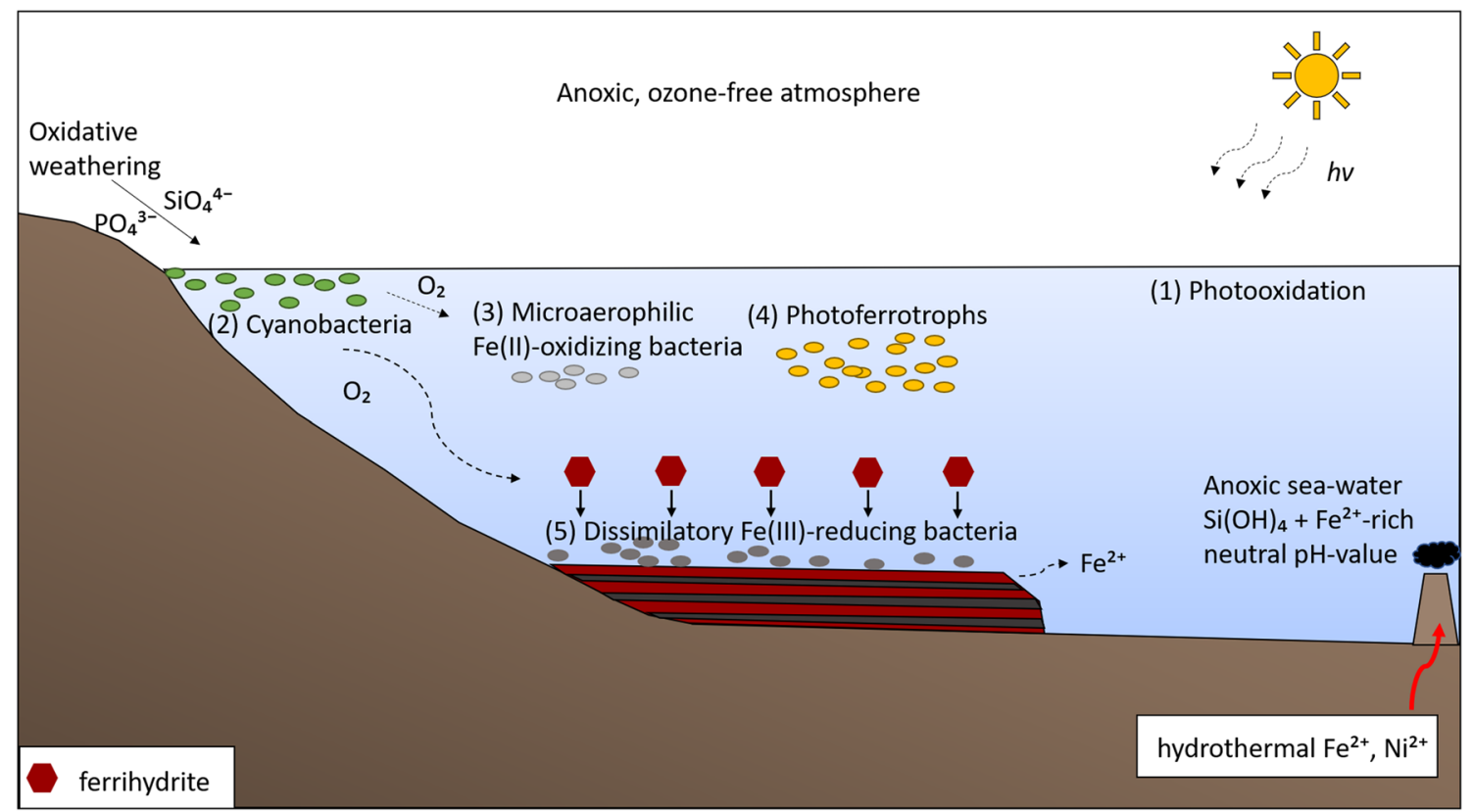

Fig. 2 Overview of biotic and abiotic Banded Iron Formations (BIFs) deposition mechanisms. Precambrian seawater was anoxic, silicaand iron-rich. Silica and phosphate were transported following the weathering of rock formations, and $\mathrm{Fe}(\mathrm{II})$ and nickel were supplied by hydrothermal fluxes. 1. Abiotic photooxidation of $\mathrm{Fe}$ (II) by UV radiation, directly leading to abiotic formation of $\mathrm{Fe}(\mathrm{III}) ; 2$. Oxygen produced by cyanobacteria leading to abiotic oxidation of dissolved
$\mathrm{Fe}(\mathrm{II})$ to form $\mathrm{Fe}(\mathrm{III})$ minerals; 3. Microaerophilic $\mathrm{Fe}(\mathrm{II})$-oxidizing bacteria reducing oxygen produced by cyanobacteria for direct oxidation of $\mathrm{Fe}(\mathrm{II})_{(\mathrm{aq})}$ to $\mathrm{Fe}(\mathrm{III})$ minerals; 4. Direct oxidation of dissolved $\mathrm{Fe}(\mathrm{II})$ by phototrophic $\mathrm{Fe}(\mathrm{II})$-oxidizing (photoferrotrophic) bacteria and 5. partial reduction of deposited Fe(III) minerals to mixedvalence state $\mathrm{Fe}(\mathrm{II}) \mathrm{Fe}(\mathrm{III})$ minerals by dissimilatory iron(III)-reducing bacteria (DIRB) 
to $\mathrm{Fe}(\mathrm{III})$ mineral deposition by direct (enzymatically driven) Fe(II) oxidation (Chan et al. 2016; Holm 1989).

There are several lines of evidence suggesting that BIF formation may not be limited to cyanobacteria (Garrels et al. 1973; Hartman 1984; Widdel et al. 1993). The assumption that cyanobacteria played a role in BIF deposition is partially founded on microfossils in the Precambrian sedimentary record. However, the dating of the first cyanobacterial occurrence in these formations is highly debated, as some of the oldest microfossils are not unambiguously primary or secondary in nature (Schirrmeister et al. 2016; van Kranendonk 2006). Additionally, cyanobacteria might have suffered from ultraviolet irradiation (Mloszewska et al. 2018)) and/or Fe(II) toxicity (Swanner et al. 2015a, c), and potentially severe nutrient (e.g., phosphorous) limitations (Jones et al. 2015). These factors would have presented significant obstacles for early cyanobacteria and raise questions regarding the role cyanobacteria had in early BIF formation.

Alternatively, Garrels et al. (1973), Hartman (1984) and Widdel et al. (1993) proposed that a different microbial process may have been responsible for the oxidation of the $\mathrm{Fe}(\mathrm{II})$, even under anoxic conditions: anoxygenic, photoautotrophic $\mathrm{Fe}$ (II) oxidation (photoferrotrophy) (Fig. 2:4). Photoferrotrophic bacteria use Fe(II) as an electron donor coupled to $\mathrm{CO}_{2}$ fixation in the presence of light, resulting in the precipitation of $\mathrm{Fe}$ (III) and the formation of biomass (Bryce et al. 2018). Their habitat reaches water depths of up to $100 \mathrm{~m}$, facilitating BIF deposition even in the simultaneous presence of cyanobacteria in the overlaying water column (Kappler et al. 2005). Indeed, work by Konhauser et al. (2002) suggests that bacteria, and especially photoferrotrophic bacteria, could have deposited most, possibly even all, Fe contained in BIFs today. Although anoxygenic phototrophs may also be negatively affected by nutrient (e.g., phosphorus) limitations, this effect would be less severe than that on cyanobacteria (Jones et al. 2015). Another potential microbial metabolism contributing to direct Fe(III) precipitation, is nitrate-dependent $\mathrm{Fe}$ (II) oxidation (Weber et al. 2006). However, the presence of oxidized species, such as nitrate, in seawater is dependent on higher oxygen availability than assumed for Precambrian oceans (Oshiki et al. 2013). A major contribution to BIF deposition by these bacteria is, therefore, considered unlikely. Although indisputable conclusive evidence for the role of microorganisms in BIF deposition has not been found, there are several lines of direct and indirect evidence that support this hypothesis as discussed below.

\section{Evidence for early cyanobacteria and photoferrotrophs}

The hypothesis of microbial influence in BIF deposition is based on the widespread theory that the GOE at $2.45 \mathrm{Ga}$ was initiated by the mass occurrence of cyanobacteria (Bekker et al. 2004; Holland 2002). Critical to this hypothesis is the presence of microbes during the time of BIF deposition, which has been hypothesized mainly based on evidence of microorganisms (in this case, cyanobacteria and photoferrotrophs) in contemporaneous formations. The first robust evidence for the presence of widespread microbial life dates back to at least $3.5 \mathrm{Ga}$ and includes stromatolites (Baumgartner et al. 2019; Duda et al. 2016; Mißbach et al. 2021; van Kranendonk 2006; Wacey et al. 2006) and geochemical information such as the stable carbon compositions and molecular evidence in sedimentological kerogens (Duda et al. 2018; Hayes 1965; Schidlowski 2001). Although the metabolisms are not always clear, some of these early mats show several lines of independent evidence that point towards the existence of phototrophic bacteria, like phototactic growth (growth towards the sun), highly negative $\delta^{13} \mathrm{C}$ values and molecular clocks (a method to date the evolution of life by comparing DNA mutations of biological groups) (Allwood et al. 2009; Schirrmeister et al. 2016). Hence, cyanobacteria are a possible source of oxygen and, consequently could be (partly) responsible for the formation of BIFs.

So far, no microfossil evidence for photoferrotrophic bacteria in the Archean ocean had been documented (Posth et al. 2013). Chi Fru et al. (2013), reported fossil evidence of an ancient relative of the photoferrotroph Rhodomicrobium Vannielii in a quaternary BIF analogue, a hematiterich jasper bands from Cape Vani in the North West of Milos, Greece. Besides microfossils, research has focused on phylogenetics and ecophysiology, to examine the evolution of photoferrotrophs and the ability to adapt to different living conditions. Woese (1987) suggested that all known phototrophic strains descended from one common ancestor, which likely evolved before oxygenic cyanobacteria (Xiong 2006). Based on experimental findings and the monitoring of recent representative strains, it has been inferred that photoferrotrophs are able to adapt to a wide variety of iron-rich environments (Croal et al. 2009), suggesting that they would have been able to survive in the ancient ocean. 


\section{Stable isotope ratios as evidence for early microbial life}

Although the state of evidence for microbial life based on biomarkers and especially the microbial role in BIF formation is not unambiguously established, stable isotope ratios in the ancient rock record can support arguments for microbial life. Chemical and biological processes often influence the stable isotope composition of the geochemical phases involved; as a result, relative enrichment or depletion of specific isotopes in the product relative to the initial reservoir allows us to infer the underlying reactions. In the case of microbial metabolism, autotrophic $\left(\mathrm{CO}_{2}\right.$-fixing) activity is usually marked by a depletion of ${ }^{13} \mathrm{C}$ (relative to ${ }^{12} \mathrm{C}$ ) in the metabolic product (e.g., organic matter). To compare the depletion of different proxies, the ratio of ${ }^{13} \mathrm{C}$ to ${ }^{12} \mathrm{C}$ compared to a standard is used, termed " $\delta{ }^{13} \mathrm{C}$ ". Therefore, highly depleted organic $\delta^{13} \mathrm{C}$ values (from $\sim-10$ up to $-35 \%$ ) may indicate microbial autotrophic processes, especially photosynthesis (Schidlowski 2001). Several 3.5 to $3.2 \mathrm{Ga}$ examples of Archean kerogens display such ${ }^{13} \mathrm{C}$ depletions: some formations in Western Australia and South Africa show isotopic values from -20 to $-35 \%$ o (Altermann and Kazmierczak 2003; Tice and Lowe 2004) and samples from the late Archean, 2.59 to $2.5 \mathrm{Ga}$ old Transvaal Supergroup have organic $\delta^{13} \mathrm{C}$ ranging from -25 to $-40 \%$ (Fischer et al. 2009). Further evidence of early microbial life was given by Hayes (1983) and Eigenbrode and Freeman (2006). They interpreted $\delta^{13} \mathrm{C}$ up to $-57 \%$ values in 2.8 to 2.6 Ga Hamersley sediments to methane cycling bacteria. Unfortunately, the $\delta^{13} \mathrm{C}$ range is ambiguous as some carbon fixation processes used by phototrophic bacteria, such as the Calvin cycle or hydroxypropionate pathways (Posth et al. 2013) or metamorphism (McKirdy and Powell 1974) produce overlapping $\delta^{13} \mathrm{C}$ ranges.

The stable iron isotope ratios $\left(\delta^{56} \mathrm{Fe}\right)$ in BIF of the Archean and early Paleoproterozoic may also be used to infer early photoferrotrophy. The $\delta^{56} \mathrm{Fe}$ values of BIFs vary widely between -2.5 and $1.0 \%$ relative to values expected for lithogenic or hydrothermal sources $(-0.5$ $\% o<\delta^{56} \mathrm{Fe}<0.3 \%$ ) (Czaja et al. 2013; Johnson et al. 2003, 2020). These BIF $\delta^{56} \mathrm{Fe}$ values differ from the homogenous values of modern marine sediments with $\delta^{56} \mathrm{Fe}$ values of $0.00 \pm 0.05 \%$, and have been interpreted to reflect BIF minerals being both precipitated with equilibrium fractionation from an isotopically varying fluid, as well as indicating a microbial influence (Johnson et al. 2003, 2004; Johnson and Brian 2005; Steinhoefel et al. 2010). Planavsky et al. $(2009,2012)$ observed $\delta^{56} \mathrm{Fe}$ values of -0.66 to $+0.82 \%$ in the $1.98 \mathrm{Ga}$ old stromatolites of the Gunflint and Biwabik iron formations in the USA.
Additionally, Johnson et al. (2003) observed highly negative $\delta^{56} \mathrm{Fe}$ values in BIF magnetite (up to $-0.57 \%$ ) from the Transvaal Supergroup, South Africa. Both analyses correlate with findings of experimental setups of ferric oxyhydroxides formed by photoferrotrophs, resulting in enrichment in the heavy iron isotope and $\delta^{56} \mathrm{Fe}$ values of $1.5 \pm 0.2 \%$ o (Croal et al. 2004). However, Fe(III) oxyhydroxides formed by chemical oxidation show comparable $\delta^{56} \mathrm{Fe}$ values, making it difficult to differentiate between biotic and abiotic processes (Bullen et al. 2001). Overall, it is considered that positively fractionated $\delta^{56} \mathrm{Fe}$ values reflect the partial oxidation of iron by either abiotic or biotic means. A recent examination of triple iron isotope systematics (Heard et al. 2020) also indicates that there was extensive iron oxidation in the Archean to Paleoproterozoic ocean. While there are uncertainties associated with such proxy approaches to discerning microbial activity, the wealth of independent evidence suggests that microorganisms were involved in BIF deposition, and build a strong basis for future work.

\section{The low concentrations of organic carbon in BIFs}

One challenge to the apparent biogenicity of BIFs has been the low extent of organic carbon preservation, typically $<0.5$ wt\% (Gole and Klein 1981), and the extent of biomassmineral coprecipitation has been a subject of considerable debate. If BIF deposition was indeed controlled by bacteria, biomass would be expected to have been sedimented in association with the iron minerals. Experiments by Posth et al. (2010) and Wu et al. (2014) show the close association of photoferrotrophic cells with Fe(III) minerals, while Swanner et al. (2015b) reported similar associations between cyanobacteria cells and Fe(III) minerals. However, Thompson et al. (2019) found that photoferrotroph biomass may be deposited separately from the formed Fe(III) minerals in the presence of silica, which could potentially explain the deposition of biomass-poor BIFs. Another possible explanation for the low organic carbon contents is that the biomass precipitated with minerals was then consumed by secondary microbiological processes (see discussion below) (Posth et al. 2013, 2014). Therefore, the lack of organic carbon in BIFs may be readily reconciled with the biological formation hypothesis.

\section{Diagenesis: secondary Fe(III) reduction}

Based on the assumption that $\mathrm{Fe}(\mathrm{III})$ oxyhydroxides, such as ferrihydrite, were the sole primary mineral phase, one major question about the genesis of BIFs is: what processes were responsible for the formation of the reduced and 
mixed-valent minerals found in BIFs today? As stated earlier, BIFs are composed of secondary minerals that include magnetite, hematite, siderite, dolomite-ankerite, greenalite, stilpnomelane, and riebeckite (Bekker et al. 2010; Klein 2005; Pecoits et al. 2009), with an overall oxidation state of 2.4 (Klein and Beukes 1992). The mixed oxidation state of iron-bearing minerals, therefore, indicates the occurrence of secondary processes leading to the reduction of the primary ferrihydrite.

The mineralogy, petrology, and isotopic composition of BIFs provide evidence that microbial and metamorphic overprinting led to the observed BIF secondary mineral composition. BIFs with little metamorphic overprint provide a good opportunity to find evidence for microbial contribution to secondary mineral diagenesis. For example, microscopic, XRD, and Mössbauer spectroscopy analyses of magnetite in the 2.48 Ga Dales George BIF, Western Australia have shown the association of magnetite with $\mathrm{Fe}$ (III) acetate salt and nanocrystals of apatite, a signature often found in contemporary microbial magnetites ( $\mathrm{Li}$ et al. 2011). Additional observations, such as highly negative $\delta^{56} \mathrm{Fe}$ values $(-0.57 \%$ ) (Johnson et al. 2003; Yamaguchi et al. 2005) in magnetite-rich BIFs (Heimann et al. 2010; Johnson et al. 2008; Reddy et al. 2016; Teixeira et al. 2017) point towards microbial Fe(III) reduction during mineral diagenesis. Walker (1984) was the first to propose that dissimilatory $\mathrm{Fe}(\mathrm{III})$ reducing bacteria (DIRB) were responsible for $\mathrm{Fe}(\mathrm{III})$ reduction in the primary BIF Fe(III) minerals, based on anomalously light $\delta^{13} \mathrm{C}$ values (on average a $\delta^{13} \mathrm{C}$ value of $-10 \%$ ) observed in the carbonate minerals in BIFs.

The secondary mineralogy also has been strongly influenced by high pressure and temperature, complicating the clear identification of microbial processes. For instance, Rasmussen and Muhling (2018) have proposed that the presence of magnetite in BIFs is a reflection of the thermal decomposition of siderite during metamorphism. In an effort to better constrain the potential role of microorganisms, or derivative organic matter, during BIF diagenesis, several laboratory studies have attempted to understand and distinguish biotic from abiotic processes that lead to alteration of the primary minerals.

\section{Experimental approaches to studying BIF mineral transformation}

Some experimental studies aimed at deciphering secondary BIF mineral transformation have been concerned with dissimilatory $\mathrm{Fe}(\mathrm{III})$ reduction (DIR). Further studies have attempted to recreate the main mineral transformation pathways expected under metamorphic conditions by exposing primary $\mathrm{Fe}(\mathrm{III})$ minerals to high pressure and high temperature conditions that are representative of those unconsolidated BIF precursor sediment would have experienced during metamorphism.

Experimental studies by Beard et al. (1999) and Johnson and Brian (2005) showed that during microbial Fe(III) reduction, freshly formed dissolved $\mathrm{Fe}(\mathrm{II})$ was depleted in ${ }^{56} \mathrm{Fe}$ by up to $3 \%$ compared to the $\mathrm{Fe}(\mathrm{III})$ oxyhydroxide source. Comparable $\delta^{56} \mathrm{Fe}$ values have been documented in magnetite-rich BIFs, suggesting that the magnetite might have been formed by microbial reduction (Johnson et al. 2003; Konhauser et al. 2005; Yamaguchi et al. 2005). Based on modelling, Konhauser et al. (2005) further suggested that, under ideal conditions, up to $70 \%$ of $\mathrm{Fe}(\mathrm{III})$ minerals could have been cycled back into the water column by DIR. This implies that DIRB could indeed have been a major player during the reduction of primary $\mathrm{Fe}(\mathrm{III})$ minerals in BIFs (Fig. 2:5).

Several laboratory studies have examined the characteristics of mineral precipitates formed by DIRB which may help identify microbially formed mineral phases. It has been shown that the identity and properties of the minerals formed by DIRB depend on (i) the amount of dissolved $\mathrm{Fe}$ (II) (Zachara et al. 2002), (ii) the concentration of nutrients and trace metals (Kukkadapu et al. 2004; Sergent et al. 2011), and (iii) the amount of organic matter (Amstaetter et al. 2012; Shimizu et al. 2013; ThomasArrigo et al. 2018; Zhou et al. 2018). An exemplary strain used to examine changes in ferrihydrite is the $\mathrm{Fe}(\mathrm{III})$-reducing bacterium Shewanella oneidensis MR-1 (Han et al. 2020). For instance, Han et al. (2020) showed that magnetite can be formed by DIRB, albeit at a much slower rate than during the abiotic reaction of ferrihydrite and dissolved Fe(II). The sole exception to magnetite formation was abiotically reduced biotic ferrihydrite, in which case only goethite was formed. Recently, there has been the first approach to rebuild the microbial iron cycling during BIF deposition in the laboratory (own observation by Schad 2021). The marine photoferrotroph Chlorobium sp. N1 (Laufer et al. 2017) and a Fe(III)-reducing culture (Laufer et al. 2016) were cultivated in a media approximating Precambrian ocean composition ( $4 \mathrm{mM} \mathrm{Fe}$ (II) and $\sim 1.4 \mathrm{mM} \mathrm{Si}$ ). During alternating oxidative and reductive cycles, a mixture of $\mathrm{Fe}(\mathrm{III})$ and $\mathrm{Fe}(\mathrm{II})$ minerals was formed. Overall, the range of secondary BIF minerals, such as magnetite and siderite, can be formed under various geochemical setups, supporting the hypothesis of microbially driven $\mathrm{Fe}(\mathrm{III})$ mineral reduction during the diagenesis of BIFs.

The secondary alteration of Fe(III) minerals by DIRB can only be assumed at temperatures lower than $120^{\circ} \mathrm{C}$, which is considered suitable for microbial activity (Kashefi and Lovley 2003). In addition, thermochemical mineral transformations during metamorphism have also been suggested to have influenced the secondary mineral (trans) formation during BIF formation in addition to microbial 
activity. Experiments reconstructing low-grade metamorphism by exposing $\mathrm{Fe}(\mathrm{III})$ minerals, admixed with glucose (as a proxy for microbial biomass) to $170{ }^{\circ} \mathrm{C}$ and $1.2 \mathrm{kbar}$ for 14 days, formed mineral phases such as siderite, hematite, and magnetite (Köhler et al. 2013; Posth et al. 2013). When analyzed after prolonged storage under hydrated, oxidizing conditions, a similar experimental approach yielded hematite and lepidocrocite (Robbins et al. 2015). Instead of glucose, Halama et al. (2016) used more complex microbial biomass, and showed that under such conditions hematite and siderite but no magnetite were being formed. Additionally, it has been suggested that magnetite formed during thermal decomposition of siderite at $200-350{ }^{\circ} \mathrm{C}$ (Rasmussen and Muhling 2018). While this transformation may be applicable to highly metamorphosed BIFs that have undergone such conditions, it is unclear if magnetite found in less metamorphosed BIFs could have been formed via this process. Instead, the biogenicity of magnetite in BIFs is further supported by the results of Li et al. (2013) who demonstrated that biogenic magnetite can be preserved during low-grade metamorphism. This implies that minerals which were formed through microbial processes during sediment diagenesis would have been preserved during progressive low-grade metamorphism.

In summary, the presence of reduced or mixed-valence Fe-bearing minerals found in BIFs today may be explained by various formation pathways which are not mutually exclusive but likely rather represent a continuum of interacting processes. While highly metamorphosed BIFs have certainly undergone temperature and pressure-based mineral transformations, the magnetite in BIFs that experienced low-grade metamorphism is likely the result of early formation pathways (Li et al. 2011) and thus may show signs of biotic influence. Currently most hypotheses on BIF mineral diagenesis are built based on isolated reduction or oxidation processes. To better understand BIF deposition and post-depositional processes, it might thus be useful to link oxidation and reduction processes, in the form of Fe cycling experiments, potentially in combination with low-grade metamorphic incubations.

\section{Microbiological iron cycling: controlling factors and limitations}

Several trace elements and nutrients such as nickel (Ni) and phosphorous $(\mathrm{P})$ are capable of influencing microbial processes. Phosphorus, especially in the form of phosphate $\left(\mathrm{PO}_{4}{ }^{3-}\right)$, is a direct limiting factor for microbial growth as it is an essential nutrient for most living creatures (Tyrrell 1999). Furthermore, $P$ is often assumed to be the ultimate limiting nutrient with regards to primary productivity on geological time scales (Laakso and Schrag 2018; Tyrrell
1999). Nickel, on the other hand, is an essential trace metal cofactor for the enzymatic activity of methanogens (Zahnle et al. 2006; Zerkle 2005), and methanotrophs (Strous and Jetten 2004) and as such its availability might have influenced the redox evolution of the atmosphere-ocean system (Konhauser et al. 2009, 2015). Therefore, reconstructing the abundances and distribution of elements such as Ni and P through time, based in part of the BIF record, can provide insights into the evolution of their availability and the contemporary microbial community as well as the redox state of Earth's ocean and atmosphere (see Robbins et al. 2016) for a review). Due to their high sorptive capacities, Fe(III) oxyhydroxides, such as ferrihydrite, are substantial sinks for trace elements and other ions in solution (Cornell and Schwertmann 2003; Dzombak and Morel 1990). Therefore, BIFs have the potential to provide critical insight into marine nutrient and trace metal concentrations in the ancient oceans (Bjerrum and Canfield 2002; Konhauser et al. 2009).

\section{Phosphorous}

Phosphorous is an essential element in various biological processes and molecules. Besides its important role as a nutrient, phosphorous is part of the molecular structure of DNA and RNA, phospholipids, and cellular membranes. In general, high $\mathrm{P}$ concentrations in ancient rock formations often correlate to nutrient peaks in Earth's history and, therefore, periods of biotic expansion (Jones et al. 2015; Planavsky et al. 2010). However, the exact concentration and role of $\mathrm{P}$ during $\mathrm{BIF}$ deposition, and the associated interplay with other elements, remains debated (Bjerrum and Canfield 2002; Jones et al. 2015; Konhauser et al. 2007; Planavsky et al. 2010). In terms of $P$ concentration, BIFs are a good candidate for a proxy as they were deposited throughout much of the Archean and Paleoproterozoic, and P tends to readily adsorb on $\mathrm{Fe}$ (III) oxyhydroxides surfaces (Bjerrum and Canfield 2002; Kipp and Stuieken 2017). Based on the presumed ancient marine $\mathrm{P}$ concentrations, conclusions supporting either $\mathrm{P}$ limitation or $\mathrm{P}$ availability have been drawn with wide implications on marine conditions during this time period.

\section{BIFs as a proxy for ancient seawater phosphorous concentrations}

Most knowledge of $\mathrm{P}$ concentrations in ancient oceans is based on the $\mathrm{P} / \mathrm{Fe}$ ratios in iron formations (IFs). IF contain not only BIFs but also granular iron formations that lack the typical banding (Robbins et al. 2016). Phosphorous to iron ratios through time are displayed in Fig. 3a (Planavsky et al. 2010; Robbins et al. 2016), and document 
Fig. 3 a Molar P/Fe concentrations in iron formations (IF) from $4 \mathrm{Ga}$ to today, replotted using data from Robbins et al. (2016) and Planavsky et al. (2010); BIF deposition between 3.8 to $1.85 \mathrm{Ga}$, Great Oxidation Event (GOE) between 2.45 to $2.32 \mathrm{Ga}$; no IF record during the Mesoproterozoic gap between $\sim 1.6$ and $\sim 0.7 \mathrm{Ga}$. Distal hydrothermal sediments are included to extend the record into the Phanerozoic. For sample filtering criteria see Planavsky et al. (2010). (b) Possible scenarios depicting the relationship between $P$ contents in IFs and seawater P concentrations; scenario (1): all dissolved $\mathrm{P}$ (in the form of phosphate) adsorbs to $\mathrm{Fe}(\mathrm{III})$ minerals, therefore, the IF P/Fe ratio displays sea water concentration; scenario (2): a wide range of ions adsorb to ferrihydrite, some P stays in solution, therefore, sea water concentration of $\mathrm{P}$ is higher than indicated based the $\mathrm{P} / \mathrm{Fe}$ ratio in the IF record as the surface of the ferrihydrite is passivated by the adsorption of other ions and less reactive to $\mathrm{P}$; $\mathrm{X}^{2+}=$ divalent cations; orange hexagons $=$ ferrihydrite

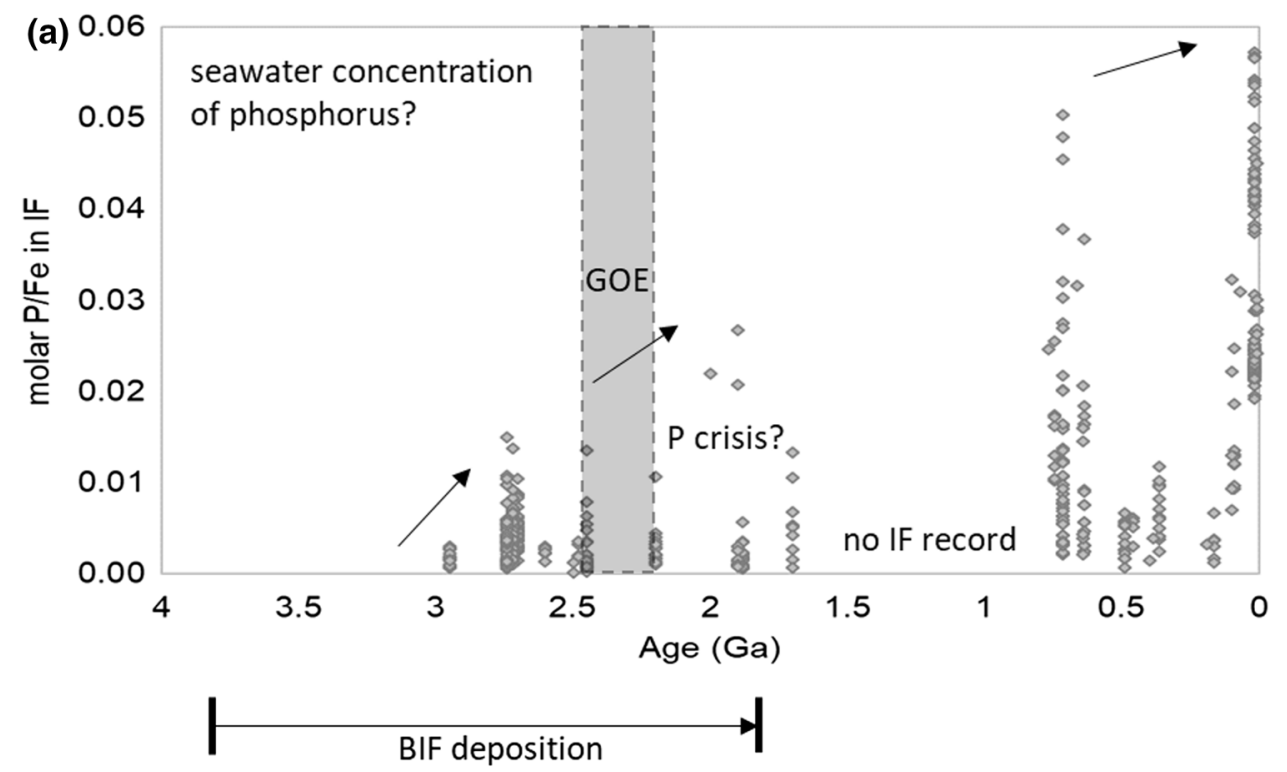

(b)

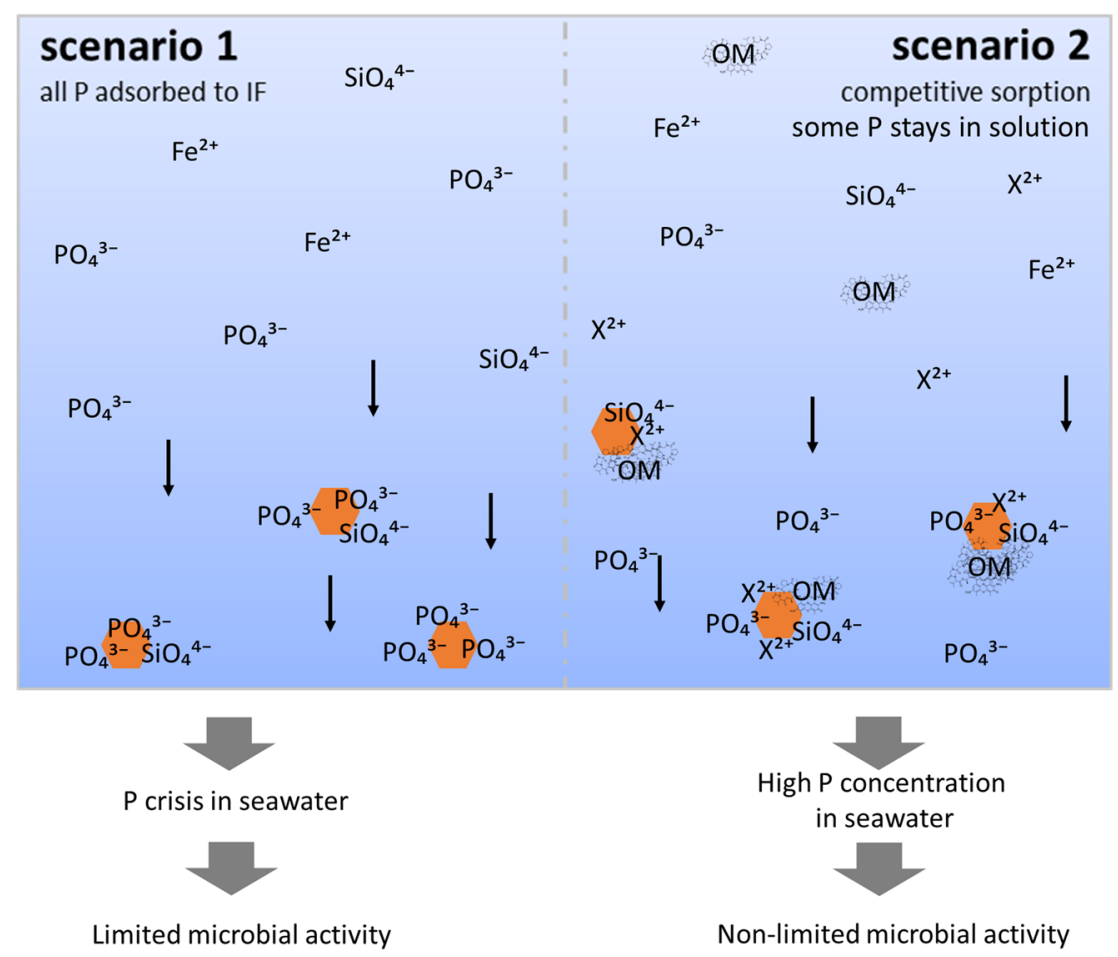

fluctuations in the $\mathrm{P} / \mathrm{Fe}$ ratios from 3 to $1.85 \mathrm{Ga}$ and from $0.75 \mathrm{Ga}$ to today. A characteristic lack of IF records results in the Mesoproterozoic gap (from 1.6 to $0.7 \mathrm{Ga}$ ), but Fig. 3a includes distal hydrothermal sediments to extend the record into the Phanerozoic. The $\mathrm{P} / \mathrm{Fe}$ ratios of IFs appear to show an overall increasing trend through time: $\mathrm{P} / \mathrm{Fe}$ ratios appear to increase from $\sim 0.005$ at $3.0 \mathrm{Ga}$ to $\sim 0.015$ at $1.85 \mathrm{Ga}$, and ultimately to modern values of between 0.05 and 0.06 .
The interpretation of the $\mathrm{P} / \mathrm{Fe}$ ratios in IFs is ambiguous. It is highly debated if lower $\mathrm{P} / \mathrm{Fe}$ ratios prior to $1.85 \mathrm{Ga}$ (Fig. 3a) reflect lower seawater $\mathrm{P}$ concentrations and if so, why the phosphorus concentrations during the time of BIF deposition were much lower than modern concentrations $(\sim 2.3 \mu \mathrm{M})$ (Bruland 1980; Bruland and Lohan 2003). Bjerrum and Canfield (2002) suggested that the low $\mathrm{P} / \mathrm{Fe}$ ratios reflect low seawater $\mathrm{P}$ concentrations of between 0.15 to $0.6 \mu \mathrm{M}$ and thus represent a $\mathrm{P}$ crisis (Fig. $3 \mathrm{~b}$ scenario 1 ). This interpretation is based on the observation that $\mathrm{P}$ (in 
the form of phosphate) readily adsorbs to Fe(III) oxyhydroxides in the absence of competing ions. Such adsorption behavior of $\mathrm{P}$ on $\mathrm{Fe}$ (III) minerals has been observed near modern hydrothermal vents (Feely et al. 1990, 1998; Klein and Beukes 1992) and low $\mathrm{P} / \mathrm{Fe}$ ratios would thus reflect low aqueous $\mathrm{P}$ concentrations.

Konhauser et al. (2007), however, challenged the hypothesis of a P crisis (Fig. 3b scenario 2), based on the high silica concentrations that would have characterized the ancient ocean (up to $2.2 \mathrm{mM}$ ) (Maliva et al. 2005; Siever 1992). For comparison, modern oceans have dissolved silica concentrations on the order of $\sim 0.1 \mathrm{mM}$ (Bruland and Lohan 2003). Experimental results presented by Konhauser et al. (2007) showed that Si effectively outcompetes P for sorption sites on $\mathrm{Fe}(\mathrm{III})$ oxyhydroxides, thus limiting $\mathrm{P}$ adsorption and resulting in the observed low $\mathrm{P} / \mathrm{Fe}$ ratios in deposited iron minerals. In this case, the low $\mathrm{P} / \mathrm{Fe}$ ratios would thus reflect much higher dissolved $\mathrm{P}$ concentrations but attenuated adsorption due to the influence of elevated marine silica concentrations (Konhauser et al. 2007). Planavsky et al. (2010) further inferred that the P concentrations at the time of BIF deposition might have been similar or even higher than modern concentrations. However, a subsequent study by Jones et al. (2015) showed that divalent cations such as $\mathrm{Mg}^{2+}$ and $\mathrm{Ca}^{2+}$ limit the influence that Si has on P adsorption. Based on their experimental results they suggested that early marine $\mathrm{P}$ concentrations would have ranged from 0.04 to $0.13 \mu \mathrm{M}$ during IF deposition, which is 13 to 58 times lower than modern marine concentrations. Another factor to consider is the co-precipitation of organic matter with $\mathrm{Fe}(\mathrm{III})$ oxyhydroxides. Organic matter preferentially adsorbs to $\mathrm{Fe}$ (III) minerals compared to $\mathrm{P}$ ( $\mathrm{Li}$ et al. 2011; Sundman et al. 2016; Yan et al. 2016), which, similar to Si, would potentially have resulted in higher dissolved $\mathrm{P}$ concentrations (see Fig. 3b). Collectively, these results suggest that although we have a good understanding of the individual factors influencing the initial adsorption of $\mathrm{P}$ to primary $\mathrm{Fe}(\mathrm{III})$ oxyhydroxides, the interpretation of the $\mathrm{P}$ contents in IFs remains elusive due to (i) lack of consensus on how multiple factors affect sorption, and (ii) a poor understanding of processes influencing post-deposition $\mathrm{P}$ mobility. The former also highlights the difficulty in drawing robust conclusions from the ancient rock record based on experimental, empirical models for trace element adsorption.

\section{Implications of oceanic phosphorus concentrations for early microbial life}

The concentrations of $\mathrm{P}$ that limit microbial growth are still poorly constrained. Further, it is unclear how this limitation may have affected the potential role of cyanobacteria to BIF deposition. Depending on the exact interpretation of the BIF record (see above discussion on factors regarding adsorption), $\mathrm{P}$ may not necessarily have been a limiting factor. Jones et al. (2015) concluded based on P sorption experiments that phosphorus concentrations would have been as low as 0.04 to $0.13 \mu \mathrm{M}$. These concentrations are too low for cyanobacterial activity, and the authors suggested that such P-starved conditions were better suited to photoferrotrophs. Papineau et al. (2013) further stated that additional phosphorous from chemical oxidative weathering had to be washed into the ocean to support cyanobacterial activity. Conversely, as Konhauser et al. (2007) and Planavsky et al. (2010) interpreted concentrations similar to or higher than modern concentrations, $\mathrm{P}$ would not have been limiting for cyanobacterial growth. This interpretation is further supported by Rasmussen et al. (2021), who found high concentrations of the phosphate mineral apatite closely associated with greenalite in BIFs. Based on the assumption that greenalite, not $\mathrm{Fe}$ (III) oxyhydroxides, is the primary mineral in BIFs, this finding led to the conclusion that phosphate is also sourced from hydrothermal vent plumes and that the $\mathrm{P}$ concentration in seawater would have been considerably higher. An additional line of evidence in support of abundant $\mathrm{P}$ for microbial growth is the finding that DIRB may cause a release of 3-25\% of adsorbed $\mathrm{P}$ via the reduction of $\mathrm{Fe}(\mathrm{III})$ minerals (Roden and Edmonds 1997). This potential release may have in turn benefited cyanobacteria or other P-limited microbes. Outstanding questions about $\mathrm{P}$ limitation may be addressed through experimental studies that target understanding phosphorus mobility during microbial Fe cycling experiments with co-cultures of cyanobacteria (or photoferrotrophs) and DIRB.

\section{Nickel}

Nickel is a trace element that is critical to prokaryotic metalloenzymes and also part of several enzymes that participate in ureolysis, hydrogenotrophy, methanogenesis, and acetogenesis (Hausinger 1987). Particularly relevant to early Earth geobiology is methanogenesis; all known methane hydrogenases contain Ni. Further, the methyl coenzyme M reductase, found in all methanogenic bacteria, possesses a nickel-containing cofactor-F430. Thus, ancient marine concentrations of Ni may have directly controlled the abundance and distribution of methanogens. This, in turn, may have impacted atmospheric concentrations of oxygen (Konhauser et al. 2009, 2015). For example, a decrease in the available Ni would have inhibited the activity of methanogens, allowing for the spread of oxygen-producing cyanobacteria. In addition, Ni-containing hydrogenases are also known to be important for phototrophs (Hausinger 1987). Thus, the availability of $\mathrm{Ni}$ as a micronutrient in the ancient 
oceans has been interpreted as a control on methanogenic and phototrophic activity.

\section{BIFs as a proxy for ancient seawater nickel concentrations}

Early efforts to determine nickel concentrations in the ancient oceans were based largely on geochemical modeling and indirect data such as the $\delta^{34} \mathrm{~S}$ sulfide isotopic record (Saito et al. 2003). In both iron and sulfide-dominated ocean scenarios, seawater Ni concentrations have been suggested to be likely uniform through time (Saito et al. 2003). This interpretation was based on experimental evidence that $\mathrm{Ni}$ (i) is not a redox-sensitive element, and, therefore, would be relatively unaffected by oxic and anoxic transitions and (ii) that $\mathrm{Ni}$ and other trace metals react with sulfide, forming strong sulfide complexes that influence the bioavailability of metals and, therefore, the emergence of microorganisms. However, compilations of $\mathrm{Ni}$ data in BIF indicate nearly constant $\mathrm{Ni} /$ Fe ratios at about $5 \times 10^{-4}$ from $4 \mathrm{Ga}$ to $2.5 \mathrm{Ga}$, followed by a marked, unidirectional decline thereafter (Konhauser et al. 2009, 2015). The youngest BIFs (e.g., the Yerbal formation, Uruguay), from $0.5 \mathrm{Ga}$ ago, show slightly increasing ratios up to $2 \times 10^{-4}$. The decrease in $\mathrm{Ni} / \mathrm{Fe}$ has been attributed to cooling of the mantle and the subsequent decrease in available Ni-rich rocks for weathering and transport (Konhauser et al. 2009, 2015; Liu et al. 2021).

The Ni/Fe ratios in BIFs have, in turn, been used to constrain dissolved Ni concentrations in the oceans through time. Such constraints are interpreted based on experimentally derived partitioning coefficients determined via laboratory-based experiments. The estimated dissolved Ni concentrations range from almost 40 to $400 \mathrm{nM}$ in the Archean (dependent on dissolved silica concentrations) to values of $9 \mathrm{nM}$ in the late Paleoproterozoic to Neoproterozoic (Konhauser et al. 2009). As the presence of silica suppresses $\mathrm{Ni}$ sorption and incorporation in a similar fashion to $\mathrm{P}$, higher assumed silica concentrations result in higher estimates of dissolved Ni. In the case of $2.2 \mathrm{mM} \mathrm{Si}$, the Ni concentration has been estimated to drop off sharply from $400 \mathrm{~nm}$ to $<200 \mathrm{nM}$ around $2.5 \mathrm{Ga}$. This has significant implications for methanogens. Below $200 \mathrm{nM} \mathrm{Ni}$, methanogenic activity has been shown to be severely limited (Kida et al. 2001; Schönheit et al. 1979). Further reports of Ni partitioning in biogenic ferrihydrite suggest that $\mathrm{Ni}$ concentrations may have been even higher in Archean oceans (Eickhoff et al. 2014), lending support to the hypothesis that methanogens were widespread. Evidence supporting the relevance of methanogenic and methanotrophic bacteria at the time of BIF deposition was also given by Hayes (1983) and Eigenbrode and Freeman (2006). They linked highly negative $\delta^{13} \mathrm{C}$ ratios between $-57 \%$ o to $-37 \%$ in kerogen from the
Hamersley province 2.8 to $2.6 \mathrm{Ga}$ old sediments to methane cycling, which ultimately led to the deposition of the ${ }^{13} \mathrm{C}$ depleted organic matter.

\section{Experimental work describing nickel partitioning and mobility}

Several experimental studies have assessed the partitioning and subsequent diagenetic mobility of nickel adsorbed to ferrihydrite in order to quantify Ni retention and mobility. Konhauser et al. (2009) demonstrated that the presence of silica decreases the amount of adsorbed $\mathrm{Ni}$ to ferrihydrite. This is supported by (Eickhoff et al. 2014), who examined the sorption of $\mathrm{Ni}$ during co-precipitation of $\mathrm{Ni}$ in presence of dissolved silica with ferrihydrite by freshwater photoferrotrophs (Rhodobacter ferrooxidans strain SW2) and marine photoferrotrophs (Rhodovulum iodosum). The authors found that the adsorption of Ni to ferrihydrite was lower to biogenic minerals in comparison to abiotic minerals. This lead to the hypothesis that $\mathrm{Ni}$ concentrations in seawater at the time of BIF formation might have been higher than previously interpreted (up to $400 \mathrm{nM}$ (Konhauser et al. 2009)).

Robbins et al. (2015) found evidence of similar sorption behavior of Ni to biogenic and abiogenic ferrihydrite, and further examined the mobility of Ni during subsequent temperature-pressure incubations designed to simulate diagenetic to low-grade metamorphism mineral transformations. Abiotic ferrihydrite and biogenic ferrihydrite, with high concentrations of adsorbed $\mathrm{Ni}$, were incubated at $170{ }^{\circ} \mathrm{C}$ and $1.2 \mathrm{kbar}$ in the presence or absence of glucose. Following incubation, $93 \%$ of $\mathrm{Ni}$ was retained on biogenic ferrihydrite and $91 \%$ on abiogenic ferrihydrite. In summary, iron cycling is a possible pathway to mobilize a small percentage of $\mathrm{Ni}$ initially adsorbed to BIF. However, to better quantify how much Ni may be released or taken up during formation and diagenesis, further studies should include experiments specifically designed to investigate the cycling of $\mathrm{Ni}$ between the dissolved pool and iron mineral phase under conditions representative of ancient oceans, as well as the mobility during higher degrees of metamorphism.

\section{Conclusions and perspectives}

Our knowledge on BIF genesis is based on a combination of theoretical and geochemical models, analysis of the ancient rock record, and laboratory simulations of early Earth conditions. Although the lack of direct micro fossil evidence makes it difficult to unambiguously identify a microbial role in BIF deposition, several independent lines of argument point towards the biogenicity of BIFs. Precambrian ocean geochemistry, defined by its anoxic, iron and 
silica-rich environment, has been shown to be hospitable for several microbial metabolisms, including cyanobacteria, photoferrotrophs, and DIRB based on experimental studies. These microorganisms may have been the key players in Precambrian iron cycling in marine systems, and ultimately led to the mineralogy we find in BIFs today. Accordingly, abiotic deposition mechanisms, such as direct Fe(II)-silica mineral precipitation (instead of Fe(III) minerals) and photooxidation of $\mathrm{Fe}(\mathrm{II})$, may have played a much smaller role than recently suggested. The precipitation of BIFs by the biotic or abiotic oxidation of dissolved $\mathrm{Fe}$ (II) would further support their continued use as proxies for reconstructing ancient nutrient and trace metal levels, as has been the case for phosphorus and nickel. Phosphorus scarcity (leading to the inhibition of microbial activity), or nickel abundance (stimulating counteracting methanogens, producing methane, which acts as a sink for oxygen), can be at least partly ruled out by recent experimental work. Previous research on elucidating the role of microorganisms in BIFs has focused mostly on individual $\mathrm{Fe}(\mathrm{II})$-oxidizing or $\mathrm{Fe}(\mathrm{III})$-reducing processes. The combination of these processes, however, is critically important. Future experiments aimed at recreating Fe cycling during BIF deposition with consortia of Fe(II)oxidizing and $\mathrm{Fe}$ (III)-reducing bacteria, coupled with further investigations of nutrient and trace metal mobility in presence of different iron minerals, are necessary to discern processes occurring during the deposition and diagenesis of BIFs and better interpret early Earth conditions.

Acknowledgements We would like to thank the reviewers and editors for their helpful comments that greatly improved the manuscript. We also thank Jan-Peter Duda and Mark Barley for kindly providing photographs of Banded Iron Formations (BIFs).

Funding Open Access funding enabled and organized by Projekt DEAL. This work was funding by Deutsche Forschungsgemeinschaft and the Natural Sciences and Engineering Research Council of Canada.

Open Access This article is licensed under a Creative Commons Attribution 4.0 International License, which permits use, sharing, adaptation, distribution and reproduction in any medium or format, as long as you give appropriate credit to the original author(s) and the source, provide a link to the Creative Commons licence, and indicate if changes were made. The images or other third party material in this article are included in the article's Creative Commons licence, unless indicated otherwise in a credit line to the material. If material is not included in the article's Creative Commons licence and your intended use is not permitted by statutory regulation or exceeds the permitted use, you will need to obtain permission directly from the copyright holder. To view a copy of this licence, visit http://creativecommons.org/licenses/by/4.0/.

\section{References}

Alibert, C. 2016. Rare earth elements in Hamersley BIF minerals. Geochimica et Cosmochimica Acta 184: 311-328. https://doi.org/10. 1016/j.gca.2016.03.026.
Allwood, A.C., J.P. Grotzinger, A.H. Knoll, I.W. Burch, M.S. Anderson, M.L. Coleman, and I. Kanik. 2009. Controls on development and diversity of Early Archean stromatolites. Proceedings of the National Academy of Sciences of the United States of America 106(24): 9548-9555. https://doi.org/10.1073/pnas.0903323106.

Altermann, W., and J. Kazmierczak. 2003. Archean microfossils: A reappraisal of early life on Earth. Research in Microbiology 154: 611-617. https://doi.org/10.1016/j.resmic.2003.08.006.

Amstaetter, K., T. Borch, and A. Kappler. 2012. Influence of humic acid imposed changes of ferrihydrite aggregation on microbial Fe(III) reduction. Geochimica et Cosmochimica Acta 85: 326341. https://doi.org/10.1016/j.gca.2012.02.003.

Bau, M., and P. Möller. 1993. Rare earth element systematics of the chemically precipitated component in early precambrian iron formations and the evolution of the terrestrial atmospherehydrosphere-lithosphere system. Geochimica et Cosmochimica Acta 57(10): 2239-2249. https://doi.org/10.1016/0016-7037(93) 90566-F.

Baumgartner, R.J., M.J. van Kranendonk, D. Wacey, M.L. Fiorentini, M. Saunders, S. Caruso, A. Pages, M. Homann, and P. Guagliardo. 2019. Nano-porous pyrite and organic matter in 3.5-billion-year-old stromatolites record primordial life. Geology 47(11): 1039-1043. https://doi.org/10.1130/G46365.1.

Beard, B.L., C.M. Johnson, L. Cox, H. Sun, K.H. Nealson, and C. Aguilar. 1999. Iron isotope biosignatures. Science 285(5435): 1889-1892. https://doi.org/10.1126/science.285.5435.1889.

Bekker, A., H.D. Holland, P.-L. Wang, D. Rumble, H.J. Stein, J.L. Hannah, L.L. Coetzee, and N.J. Beukes. 2004. Dating the rise of atmospheric oxygen. Nature 427(6970): 117-120. https:// doi.org/10.1038/nature02260.

Bekker, A., J.F. Slack, N.J. Planavsky, B. Krapež, A. Hofmann, K.O. Konhauser, and O.J. Rouxel. 2010. Iron formation: A sedimentary product of the complex interplay among mantle, tectonic, and biospheric processes. Economic Geology 150(3): 467-508. https://doi.org/10.2113/gsecongeo.105.3.467.

Bekker, A., N. Planavsky, B. Rasmussen, B. Krapez, A. Hofmann, J.F. Slack, O.J. Rouxel, and K.O. Konhauser. 2014. Iron formations: Their origin and implications for ancient seawater chemistry. Treatise of Geochemistry 9: 561-628. https://doi. org/10.1016/B978-0-08-095975-7.00719-1.

Beukes, N.J. 1984. Sedimentology of the Kuruman and Griquatown iron-formations, transvaal supergroup, Griqualand West, South Africa. Precambrian Research 24(1): 47-84. https://doi.org/10. 1016/0301-9268(84)90069-X.

Beukes, N.J., and J. Gutzmer. 2008. Origin and paleoenvironmental significance of major iron formations at the Archean-Paleoproterozoic boundary. Reviews in Economic Geology 15: 5-47. https://doi.org/10.5382/Rev.15.01.

Bjerrum, C.J., and D.E. Canfield. 2002. Ocean productivity before about 1.9 Gyr ago limited by phosphorus adsorption onto iron oxides. Nature 417(6885): 159-162. https://doi.org/10.1038/ 417159a.

Braterman, P.S., A.G. Cairns-Smith, and R.W. Sloper. 1983. Photooxidation of hydrated $\mathrm{Fe}^{2+}$ - significance for banded iron formations. Nature 303(5913): 163-164. https://doi.org/10.1038/ $303163 \mathrm{a} 0$.

Bruland, K.W. 1980. Oceanographic distributions of cadmium, zinc, nickel, and copper in the North Pacific. Earth and Planetary Science Letters 47(2): 176-198. https://doi.org/10.1016/0012821X(80)90035-7.

Bruland, K.W., and M.C. Lohan. 2003. Controls of Trace Metals in Seawater. Treatise of Geochemistry 6: 23-47. https://doi.org/ 10.1016/B0-08-043751-6/06105-3.

Bryce, C., N. Blackwell, C. Schmidt, J. Otte, Y.-M. Huang, S. Kleindienst, E. Tomaszewski, M. Schad, V. Warter, C. Peng, et al. 2018. Microbial anaerobic Fe(II) oxidation-Ecology, 
mechanisms and environmental implications. Environmental Microbiology 20(10): 3462-3483. https://doi.org/10.1111/ 1462-2920.14328.

Buick, R. 2008. When did oxygenic photosynthesis evolve? Philosophical Transactions of the Royal Society of London (B: Biological Sciences) 363(1504): 2731-2743. https://doi.org/10.1098/rstb. 2008.0041.

Bullen, T.D., A.F. White, C.W. Childs, D.V. Vivit, and M.S. Schulz. 2001. Demonstration of significant abiotic iron isotope fractionation in nature. Geology 29(8): 699. https://doi.org/10.1130/00917613(2001)029\%3c0699:DOSAII\%3e2.0.CO;2.

Cairns-Smith, A.G. 1978. Precambrian solution photochemistry, inverse segregation, and banded iron formations. Nature 276(5690): 807-808. https://doi.org/10.1038/276807a0.

Catling, D.C., and K.J. Zahnle. 2020. The Archean Atmosphere. Science Advances 6(9): 1-16. https://doi.org/10.1089/1531107027 53621321.

Chan, C.S., D. Emerson, and G.W. Luther. 2016. The role of microaerophilic $\mathrm{Fe}$-oxidizing micro-organisms in producing banded iron formations. Geobiology 14(5): 509-528. https://doi.org/10. 1111/gbi.12192.

Chi Fru, E., M. Ivarsson, S.P. Kilias, S. Bengtson, V. Belivanova, F. Marone, D. Fortin, C. Broman, and M. Stampanoni. 2013. Fossilized iron bacteria reveal a pathway to the biological origin of banded iron formation. Nature Communications 4: 2050. https:// doi.org/10.1038/ncomms3050.

Cloud, P. 1965. Significance of the Gunflint (Precambrian) Microflora. Science 148: 27-35. https://doi.org/10.1126/science.148.3666. 27.

Cloud, P. 1973. Paleoecological Significance of the Banded Iron-Formation. Economic Geology 68(7): 1135-1143. https://doi.org/ 10.2113/gsecongeo.68.7.1135.

Cornell, Rochelle M., and Udo Schwertmann. 2003. The Iron Oxides. Structure, Properties, Reactions, Occurences and Uses, 2 nd ed. Weinheim: Wiley-VCH.

Croal, L.R., C.M. Johnson, B.L. Beard, and D.K. Newman. 2004. Iron isotope fractionation by $\mathrm{Fe}(\mathrm{II})$-oxidizing photoautotrophic bacteria Geochimica et Cosmochimica Acta 68(6): 1227-1242. https:// doi.org/10.1016/j.gca.2003.09.011.

Croal, L.R., Y. Jiao, A. Kappler, and D.K. Newman. 2009. Phototrophic $\mathrm{Fe}(\mathrm{II})$ oxidation in an atmosphere of $\mathrm{H}_{2}$ : Implications for Archean banded iron formations. Geobiology 7(1): 21-24. https://doi.org/10.1111/j.1472-4669.2008.00185.x.

Czaja, A.D., C.M. Johnson, E.E. Roden, B.L. Beard, A.R. Voegelin, T.F. Nägler, N.J. Beukes, and M. Wille. 2012. Evidence for free oxygen in the Neoarchean ocean based on coupled iron-molybdenum isotope fractionation. Geochimica et Cosmochimica Acta 86: 118-137. https://doi.org/10.1016/j.gca.2012.03.007.

Czaja, A.D., C.M. Johnson, B.L. Beard, E.E. Roden, W. Li, and S. Moorbath. 2013. Biological Fe oxidation controlled deposition of banded iron formation in the ca. 3770Ma Isua Supracrustal Belt (West Greenland). Earth and Planetary Science Letters 363: 192-203. https://doi.org/10.1016/j.eps1.2012.12.025.

Dimroth, E., and J.J. Chauvel. 1973. Petrography of the Sokoman iron formation in part of the central Labrador trough. Geological Society of America Bulletin 84(1): 111-134. https://doi.org/10. 1130/0016-7606(1973)84\%3C111:POTSIF\%3E2.0.CO;2.

Duda, J.-P., M.J. van Kranendonk, V. Thiel, D. Ionescu, H. Strauss, N. Schäfer, and J. Reitner. 2016. A Rare Glimpse of Paleoarchean Life: Geobiology of an Exceptionally Preserved Microbial Mat Facies from the 3.4 Ga Strelley Pool Formation, Western Australia. PLoS ONE 11(1): e0147629. https://doi.org/10.1371/journ al.pone.0147629.

Duda, J.-P., V. Thiel, T. Bauersachs, H. Mißbach, M. Reinhardt, N. Schäfer, M.J. van Kranendonk, and J. Reitner. 2018. Ideas and perspectives: Hydrothermally driven redistribution and sequestration of early Archaean biomass-the "hydrothermal pump hypothesis." Biogeosciences 15(5): 1535-1548. https:// doi.org/10.5194/bg-15-1535-2018.

Dzombak, D.A., and F. Morel. 1990. Surface Complexation Modeling. Wiley Interscience. https://doi.org/10.1002/9780470642665.

Eickhoff, M., M. Obst, C. Schröder, A.P. Hitchcock, T. Tyliszczak, R.E. Martinez, L.J. Robbins, K.O. Konhauser, and A. Kappler. 2014. Nickel partitioning in biogenic and abiogenic ferrihydrite: The influence of silica and implications for ancient environments. Geochimica et Cosmochimica Acta 140: 65-79. https://doi.org/ 10.1016/j.gca.2014.05.021.

Eigenbrode, J.L., and K.H. Freeman. 2006. Late Archean rise of aerobic microbial ecosystems. Proceedings of the National Academy of Sciences of the United States of America 103(43): 1575915764. https://doi.org/10.1073/pnas.0607540103.

Ernst, D.M., and M. Bau. 2021. Banded iron formation from Antarctica: The $2.5 \mathrm{Ga}$ old Mt. Ruker BIF and the antiquity of lanthanide tetrad effect and super-chondritic Y/Ho ratio in seawater. Gondwana Research. https://doi.org/10.1016/j.gr.2020.11.011.

Farquhar, J., A.L. Zerkle, and A. Bekker. 2011. Geological constraints on the origin of oxygenic photosynthesis. Photosynthesis Research 107(1): 11-36. https://doi.org/10.1007/ s11120-010-9594-0.

Feely, R.A., J.H. Trefry, G.J. Massoth, and S. Metz. 1990. A comparison of the scavenging of phosphorus and arsenic from seawater by hydrothermal iron oxyhydroxides in the Atlantic and Pacific Oceans. Deep-Sea Research 38(6): 617-623. https://doi.org/10. 1016/0198-0149(91)90001-V.

Feely, R.A., J.H. Trefry, G.T. Lebon, and G.R. German. 1998. The Relationship between P/Fe and V/Fe Ratios in Hydrothermal Precipitates and Dissolved Phosphate in Seawater. Geophysical Research Letters 25(13): 2253-2256. https://doi.org/10.1029/ 98 GL01546.

Fischer, W.W., S. Schroeder, J.P. Lacassie, N.J. Beukes, T. Goldberg, H. Strauss, U.E. Horstmann, D.P. Schrag, and A.H. Knoll. 2009. Isotopic constraints on the Late Archean carbon cycle from the Transvaal Supergroup along the western margin of the Kaapvaal Craton, South Africa. Precambrian Research 169(1-4): 15-27. https://doi.org/10.1016/j.precamres.2008.10.010.

Garrels, R.M., E.A. Perry Jr., and F.T. MacKenzie. 1973. Genesis of Precambrian Iron-Formations and the Development of Atmospheric Oxygen. Economic Geology 68(7): 1173-1179. https:// doi.org/10.2113/gsecongeo.68.7.1173.

Gole, M.J., and C. Klein. 1981. Banded Iron-Formations through Much of Precambrian Time. The Journal of Geology 89(2): 169-183. https://doi.org/10.1086/628578.

Halama, M., E.D. Swanner, K.O. Konhauser, and A. Kappler. 2016. Evaluation of siderite and magnetite formation in BIFs by pressure-temperature experiments of $\mathrm{Fe}(\mathrm{III})$ minerals and microbial biomass. Earth and Planetary Science Letters 450: 243-253. https://doi.org/10.1016/j.eps1.2016.06.032.

Halevy, I., M. Aleksker, E.M. Schuster, R. Popovitz-Biro, and Y. Feldman. 2017. A key role for green rust in the Precambrian oceans and the genesis of iron formations. Nature Geoscience 10: 135139. https://doi.org/10.1038/ngeo2878.

Hamade, T., K.O. Konhauser, R. Raiswell, S. Goldsmith, and R.C. Morris. 2003. Using Ge/Si ratios to decouple iron and silica fluxes in Precambrian banded iron formations. Geology 31(1): 35. https://doi.org/10.1130/0091-7613(2003)031\%3c0035: UGSRTD\%3e2.0.CO;2.

Han, T.-M. 1966. Textural relations of hematite and magnetite in some Precambrian metamorphosed oxide iron-formations. Economic Geology 61: 1306-1310.

Han, T.-M. 1978. Microstructures of magnetite as guides to its origin in some Precambrian iron-formations. Fortschritte in der Mineralogie 56(1): 105-142. 
Han, X., E.J. Tomaszewski, J. Sorwat, Y. Pan, A. Kappler, and J.M. Byrne. 2020. Effect of Microbial Biomass and Humic Acids on Abiotic and Biotic Magnetite Formation. Environmental Science \& Technology 54(7): 4121-4130. https://doi.org/10.1021/acs.est. 9b07095.

Harder, H. 1976. Nontronite synthesis at low temperatures. Chemical Geology 18(3): 169-180. https://doi.org/10.1016/0009-2541(76) 90001-2.

Harder, H. 1978. Synthesis of Iron Layer Silicate Minerals under Natural Conditions. Clays and Clay Minerals 26(1): 65-72. https:// doi.org/10.1346/CCMN.1978.0260108.

Hardisty, D.S., Z. Lu, N.J. Planavsky, A. Bekker, P. Philippot, X. Zhou, and T.W. Lyons. 2014. An iodine record of Paleoproterozoic surface ocean oxygenation. Geology 42(7): 619-622. https://doi.org/ 10.1130/G35439.1.

Hartman, H. 1984. The evolution of photosynthesis and microbial mats: a speculation on banded iron formations. In Microbial Mats: Stromatolites, eds. Y. Cohen, and R.W. Castenholz, 451-453. New York: Alan Liss.

Hausinger, R.P. 1987. Nickel Utilization by Microorganisms. Microbiological Reviews 51(1): 22-42.

Hayes, W.J. 1965. Review of the metabolism of chlorinated hydrocarbon insectides especially in mammals. Annual Review of Pharmacology 5: 27-52. https://doi.org/10.1146/annurev.pa. 05.040165 .000331 .

Hayes, J.M. 1983. Geochemical evidence bearing on the origin of aerobiosis, a speculative hypothesis. In Earth's Earliest Biosphere, Its Origins and Evolution, ed. J.W. Schopf, 291-301. Princeton: Princeton University Press.

Heard, A.W., N. Dauphas, R. Guilbaud, O.J. Rouxel, I.B. Butler, N.X. Nie, and A. Bekker. 2020. Triple iron isotope constraints on the role of ocean iron sinks in early atmospheric oxygenation. Science 370: 446-449. https://doi.org/10.1126/science. aaz8821.

Heimann, A., C.M. Johnson, B.L. Beard, J.W. Valley, E.E. Roden, M.J. Spicuzza, and N.J. Beukes. 2010. Fe, C, and O isotope compositions of banded iron formation carbonates demonstrate a major role for dissimilatory iron reduction in $\sim 2.5 \mathrm{Ga}$ marine environments. Earth and Planetary Science Letters 294(1-2): 8-18. https://doi.org/10.1016/j.eps1.2010.02.015.

Holland, H.D. 1973. The oceans: A possible source of iron in ironformations. Economic Geology 68: 1169-1172. https://doi.org/ 10.2113/gsecongeo.68.7.1169.

Holland, H.D. 2002. Volcanic gases, black smokers, and the great oxidation event. Geochimica et Cosmochimica Acta 66(21): 3811-3826. https://doi.org/10.1016/S0016-7037(02)00950-X.

Holm, N.G. 1989. The $13 \mathrm{C} / 12 \mathrm{C}$ ratios of siderite and organic matter of a modern metalliferous hydrothermal sediment and their implications for banded iron formations. Chemical Geology 77: 41-45. https://doi.org/10.1016/0009-2541(89)90013-2.

Isley, A.E. 1995. Hydrothermal Plumes and the Delivery of Iron to Banded Iron Formation. The University of Chicago Press Journals 103(2): 169-185.

Isley, A.E., and D.H. Abbott. 1999. Plume related mafic volcanism and the deposition of banded iron formation. Journal of Geophysical Research 104(7): 15461-15477. https://doi.org/10.1029/1999J B900066.

Jacobsen, S.B., and M.R. Pimentel-Klose. 1988. A Nd isotopic study of the Hamersley and Michipicoten banded iron formations: The source of REE and Fe in Archean oceans. Earth and Planetary Science Letters 87(1-2): 29-44. https://doi.org/10.1016/0012821X(88)90062-3.

Johnson, C.M., and B.L. Brian. 2005. Biogeochemical Cycling of Iron Isotopes. Science 309: 1025-1027. https://doi.org/10.1126/scien ce. 1112552 .
Johnson, C.M., B.L. Beard, N.J. Beukes, C. Klein, and J.M. O'Leary. 2003. Ancient geochemical cycling in the Earth as inferred from Fe isotope studies of banded iron formations from the Transvaal Craton. Contributions to Mineralogy and Petrology 144(5): 523-547. https://doi.org/10.1007/s00410-002-0418-x.

Johnson, C.M., B.L. Beard, E.E. Roden, D.K. Newman, and K.H. Nealson. 2004. Isotopic Constraints on Biogeochemical Cycling of Fe. Reviews in Mineralogy and Geochemistry 55(1): 359-408. https://doi.org/10.2138/gsrmg.55.1.359.

Johnson, C.M., B.L. Beard, C. Klein, N.J. Beukes, and E.E. Roden. 2008. Iron isotopes constrain biologic and abiologic processes in banded iron formation genesis. Geochimica et Cosmochimica Acta 72(1): 151-169. https://doi.org/10.1016/j.gca.2007.10.013.

Johnson, J.E., J.R. Muhling, J. Cosmidis, B. Rasmussen, and A.S. Templeton. 2018. Low-Fe(III) Greenalite Was a Primary Mineral From Neoarchean Oceans. Geophysical Research Letters 45(7): 3182-3192. https://doi.org/10.1002/2017GL076311.

Johnson, C., B. Beard, and S. Weyer. 2020. In The Ancient Earth. In Iron Geochemistry: An Isotopic Perspective, eds. C. Johnson, B. Beard, and S. Weyer, 215-360. Cham: Springer International Publishing (Advances in Isotope Geochemistry).

Jones, C., S. Nomosatryo, S.A. Crowe, C.J. Bjerrum, and D.E. Canfield. 2015. Iron oxides, divalent cations, silica, and the early earth phosphorus crisis. Geology 43(2): 135-138. https://doi.org/ 10.1130/G36044.1.

Kappler, A., C. Pasquero, K.O. Konhauser, and D.K. Newman. 2005. Deposition of banded iron formations by anoxygenic phototrophic Fe(II)-oxidizing bacteria. Geology 33(11): 865-868. https:// doi.org/10.1130/G21658.1.

Kashefi, K., and D.R. Lovley. 2003. Extending the Upper Temperature Limit for Life. Science 301: 934. https://doi.org/10.1126/scien ce.1086823.

Kasting, J.F. 1992. Models relating to Proterozoic atmosphere and ocean chemistry. In The Proterozoic Biosphere: A Multidisciplinary Study, eds. J.W. Schopf, and C. Klein, 1185-1187. NewYork: Cambridge University Press.

Kendall, B., T.W. Lyons, A.J. Kaufman, S.W. Poulton, and A.D. Anbar. 2010. Pervasive oxygenation along late Archaean ocean margins. Nature Geoscience 3: 647-652. https://doi.org/10.1038/ngeo942.

Kida, K., T. Shigematsu, J. Kijima, M. Numaguchi, Y. Mochinaga, N. Abe, and S. Morimura. 2001. Influence of $\mathrm{Ni}^{2+}$ and $\mathrm{Co}^{2+}$ on methanogenic activity and the amounts of coenzymes involved in methanogenesis. Journal of Bioscience and Bioengineering 91(6): 590-595. https://doi.org/10.1016/S1389-1723(01) 80179-1.

Kipp, M.A., and E.E. Stüeken. 2017. Biomass recycling and Earth's early phosphorus cycle. Science Advances 3(11): eaao4795. https://doi.org/10.1126/sciadv.aao4795.

Klein, C. 2005. Some Precambrian banded iron-formations (BIFs) from around the world: Their age, geologic setting, mineralogy, metamorphism, geochemistry, and origins. American Mineralogist 90(10): 1473-1499. https://doi.org/10.2138/am.2005.1871.

Klein, C., and N.J. Beukes. 1992. Time Distribution, Stratigraphy, and Sedimentologic Setting, and Geochemistry of Precambrian IronFormations. In The Proterozoic Biosphere: A Multidisciplinary Study, eds. J.W. Schopf, and C. Klein, 139-146. New York: Cambridge University Press.

Köhler, I., K.O. Konhauser, D. Papineau, A. Bekker, and A. Kappler. 2013. Biological carbon precursor to diagenetic siderite with spherical structures in iron formations. Nature Communications 4(1741): 1-7. https://doi.org/10.1038/ncomms2770.

Konhauser, K.O. 2011. Chromium enrichment in iron formations record Earth's first acid rock drainage during the Great Oxidation Event. Nature 478: 369-373.

Konhauser, K.O., T. Hamade, R. Raiswell, R.C. Morris, G.F. Ferris, G. Southam, and D.E. Canfield. 2002. Could bacteria have formed 
the Precambrian banded iron formations? Geology 30(12): 1079. https://doi.org/10.1130/0091-7613(2002)030\%3c1079:CBHFTP\%3e2.0.CO;2.

Konhauser, K.O., D.K. Newman, and A. Kappler. 2005. The potential significance of microbial $\mathrm{Fe}(\mathrm{III})$ reduction during deposition of Precambrian banded iron formations. Geobiology 3: 167-177. https://doi.org/10.1111/j.1472-4669.2005.00055.x.

Konhauser, K.O., S.V. Lalonde, L. Amskold, and H.D. Holland. 2007. Was there really an Archean phosphate crisis? Science 315(5816): 1234. https://doi.org/10.1126/science.1136328.

Konhauser, K.O., E. Pecoits, S.V. Lalonde, D. Papineau, E.G. Nisbet, M.E. Barley, N.T. Arndt, K. Zahnle, and B.S. Kamber. 2009. Oceanic nickel depletion and a methanogen famine before the Great Oxidation Event. Nature 458(7239): 750-753. https://doi. org/10.1038/nature07858.

Konhauser, K.O., L.J. Robbins, E. Pecoits, C. Peacock, A. Kappler, and S.V. Lalonde. 2015. The Archean Nickel Famine Revisited. Astrobiology 15(10): 804-815. https://doi.org/10.1089/ast.2015. 1301.

Konhauser, K.O., N.J. Planavsky, D.S. Hardisty, L.J. Robbins, T.J. Warchola, R. Haugaard, S.V. Lalonde, C.A. Partin, P. Oonk, H. Tsikos, et al. 2017. Iron formations: A global record of Neoarchaean to Palaeoproterozoic environmental history. EarthScience Reviews 172: 140-177. https://doi.org/10.1016/j.earsc irev.2017.06.012.

Krapež, B., M.E. Barley, and A.L. Pickard. 2003. Hydrothermal and resedimented origins of the precursor sediments to banded iron formation: Sedimentological evidence from the Early Palaeoproterozoic Brockman Supersequence of Western Australia. Sedimentology 50(5): 979-1011. https://doi.org/10.1046/j. 1365-3091.2003.00594.x.

Krissansen-Totton, J., G.N. Arney, and D.C. Catling. 2018. Constraining the climate and ocean $\mathrm{pH}$ of the early Earth with a geological carbon cycle model. Proceedings of the National Academy of Sciences of the United States of America 115(16): 4105-4110. https://doi.org/10.1073/pnas.1721296115.

Kukkadapu, R.K., J.M. Zachara, J.K. Fredrickson, and D.W. Kennedy. 2004. Biotransformation of two-line silica-ferrihydrite by a dissimilatory $\mathrm{Fe}(\mathrm{III})$-reducing bacterium: Formation of carbonate green rust in the presence of phosphate. Geochimica et Cosmochimica Acta 68(13): 2799-2814. https://doi.org/10. 1016/j.gca.2003.12.024.

Laakso, T.A., and D.P. Schrag. 2018. Limitations on Limitation. Global Biogeochemical Cycles 32(3): 486-496. https://doi.org/ 10.1002/2017GB005832.

Laufer, K., M. Nordhoff, H. Røy, C. Schmidt, S. Behrens, B.B. Jørgensen, and A. Kappler. 2016. Coexistence of Microaerophilic, Nitrate-Reducing, and Phototrophic Fe(II) Oxidizers and Fe(III) Reducers in Coastal Marine Sediment. Applied and Environmental Microbiology 82(5): 1433-1447. https:// doi.org/10.1128/AEM.03527-15.

Laufer, K., A. Niemeyer, V. Nikeleit, M. Halama, J.M. Byrne, and A. Kappler. 2017. Physiological characterization of a halotolerant anoxygenic phototrophic Fe(II)-oxidizing green-sulfur bacterium isolated from a marine sediment. FEMS Microbiology Ecology. https://doi.org/10.1093/femsec/fix054.

Li, Y., K.O. Konhauser, D.R. Cole, and T.J. Phelps. 2011. Mineral ecophysiological data provide growing evidence for microbial activity in banded-iron formations. Geological Society of America Bulletin 39(8): 707-710. https://doi.org/10.1130/ G32003.1.

Li, Y.-L., K.O. Konhauser, A. Kappler, and X.-L. Hao. 2013. Experimental low-grade alteration of biogenic magnetite indicates microbial involvement in generation of banded iron formations. Earth and Planetary Science Letters 361: 229-237. https://doi. org/10.1016/j.eps1.2012.10.025.
Liu, H., K.O. Konhauser, L.J. Robbins, and W. Sun. 2021. Global continental volcanism controlled the evolution of the oceanic nickel reservoir. Earth and Planetary Science Letters 572: 117116. https://doi.org/10.1016/j.epsl.2021.117116.

Lyons, T.W., C.T. Reinhard, and N.J. Planavsky. 2014. The rise of oxygen in Earth's early ocean and atmosphere. Nature 506(7488): 307-315. https://doi.org/10.1038/nature13068.

Maliva, R.G., A.H. Knoll, and B.M. Simonson. 2005. Secular change in the Precambrian silica cycle: Insights from chert petrology. Geological Society of America Bulletin 117(7-8): 835-845. https:// doi.org/10.1130/B25555.1.

McKirdy, D.M., and T.G. Powell. 1974. Metamorphic Alteration of Carbon Isotopic Composition in Ancient Sedimentary Organic Matter: New Evidence from Australia and South Africa. Geology 2(12): 591-595. https://doi.org/10.1130/0091-7613(1974)2\% $3 \mathrm{c} 591$.

Mißbach, H., J.-P. Duda, A.M. van den Kerkhof, V. Lüders, A. Pack, J. Reitner, and V. Thiel. 2021. Ingredients for microbial life preserved in 3.5 billion-year-old fluid inclusions. Nature Communications 12(1): 1101. https://doi.org/10.1038/ s41467-021-21323-z.

Mloszewska, A.M., D.B. Cole, N.J. Planavsky, A. Kappler, D.S. Whitford, G.W. Owttrim, and K.O. Konhauser. 2018. UV radiation limited the expansion of cyanobacteria in early marine photic environments. Nature Communications 9 (1): 3088. https://doi. org/10.1038/s41467-018-05520-x.

Moon, E.M., and C.L. Peacock. 2012. Adsorption of $\mathrm{Cu}(\mathrm{II})$ to ferrihydrite and ferrihydrite-bacteria composites: Importance of the carboxyl group for $\mathrm{Cu}$ mobility in natural environments. Geochimica et Cosmochimica Acta 92: 203-219. https://doi.org/10. 1016/j.gca.2012.06.012.

Morris, R.C. 1993. Genetic modelling for banded iron-formation of the Hamersley Group, Pilbara Craton, Western Australia. Precambrian Research 60(1-4): 243-286. https://doi.org/10.1016/ 0301-9268(93)90051-3.

Morris, R.C., and R.C. Horwitz. 1983. The origin of the iron-formation-rich Hamersley Group of Western Australia-deposition on a platform. Precambrian Research 21(3-4): 273-297. https://doi. org/10.1016/0301-9268(83)90044-X.

Nie, N.X., N. Dauphas, and R.C. Greenwood. 2017. Iron and oxygen isotope fractionation during iron UV photo-oxidation: Implications for early Earth and Mars. Earth and Planetary Science Letters 458: 179-191. https://doi.org/10.1016/j.epsl.2016.10.035.

Olson, S.L., L.R. Kump, and J.F. Kasting. 2013. Quantifying the areal extent and dissolved oxygen concentrations of Archean oxygen oases. Chemical Geology 362: 35-43. https://doi.org/10.1016/j. chemgeo.2013.08.012.

Oshiki, M., S. Ishii, K. Yoshida, N. Fujii, M. Ishiguro, H. Satoh, and S. Okabe. 2013. Nitrate-dependent ferrous iron oxidation by anaerobic ammonium oxidation (anammox) bacteria. Applied and Environmental Microbiology 79(13): 4087-4093. https:// doi.org/10.1128/AEM.00743-13.

Papineau, D., R. Purohit, M.L. Fogel, and G.A. Shields-Zhou. 2013. High phosphate availability as a possible cause for massive cyanobacterial production of oxygen in the Paleoproterozoic atmosphere. Earth and Planetary Science Letters 362: 225-236. https://doi.org/10.1016/j.epsl.2012.11.050.

Pavlov, A.A., and J.F. Kasting. 2002. Mass-Independent Fractionation of Sulfur Isotopes in Archean Sediments: Strong Evidence for an Anoxic Archean Atmosphere. Astrobiology 2(1): 27-41. https:// doi.org/10.1089/153110702753621321.

Pecoits, E., M.K. Gingras, M.E. Barley, A. Kappler, N.R. Posth, and K.O. Konhauser. 2009. Petrography and geochemistry of the Dales Gorge banded iron formation: Paragenetic sequence, source and implications for palaeo-ocean chemistry. 
Precambrian Research 172(1-2): 163-187. https://doi.org/10. 1016/j.precamres.2009.03.014.

Percak-Dennett, E.M., B.L. Beard, H. Xu, H. Konishi, C.M. Johnson, and E.E. Roden. 2011. Iron isotope fractionation during microbial dissimilatory iron oxide reduction in simulated Archaean seawater. Geobiology 9(3): 205-220. https://doi.org/10.1111/j. 1472-4669.2011.00277.x.

Perry, E.C., F.C. Tan, and G.B. Morey. 1973. Geology and stable isotope geochemistry of the Biwabik Iron Formation. Economic Geology 68(7): 1110-1125. https://doi.org/10.2113/gsecongeo. 68.7.1110.

Planavsky, N., O. Rouxel, A. Bekker, R. Shapiro, P. Fralick, and A. Knudsen. 2009. Iron-oxidizing microbial ecosystems thrived in late Paleoproterozoic redox-stratified oceans. Earth and Planetary Science Letters 286(1-2): 230-242. https://doi.org/10. 1016/j.eps1.2009.06.033.

Planavsky, N.J., O.J. Rouxel, A. Bekker, S.V. Lalonde, K.O. Konhauser, C.T. Reinhard, and T.W. Lyons. 2010. The evolution of the marine phosphate reservoir. Nature 467(7319): 1088-1090. https://doi.org/10.1038/nature09485.

Planavsky, N.J., A. Bekker, A. Hofmann, J.D. Owens, and T.W. Lyons. 2012. Sulfur record of rising and falling marine oxygen and sulfate levels during the Lomagundi event. Proceedings of the National Academy of Sciences of the United States of America 109(45): 18300-18305. https://doi.org/10.1073/pnas.11203 87109 .

Posth, N.R., S. Huelin, K.O. Konhauser, and A. Kappler. 2010. Size, density and composition of cell-mineral aggregates formed during anoxygenic phototrophic $\mathrm{Fe}(\mathrm{II})$ oxidation: Impact on modern and ancient environments. Geochimica et Cosmochimica Acta 74(12): 3476-3493. https://doi.org/10.1016/j.gca.2010.02.036.

Posth, N.R., K.O. Konhauser, and A. Kappler. 2013. Microbiological processes in banded iron formation deposition. Sedimentology 60(7): 1733-1754. https://doi.org/10.1111/sed.12051.

Posth, N.R., D.E. Canfield, and A. Kappler. 2014. Biogenic Fe(III) minerals: From formation to diagenesis and preservation in the rock record. Earth-Science Reviews 135: 103-121. https://doi. org/10.1016/j.earscirev.2014.03.012.

Rasmussen, B., and J.R. Muhling. 2018. Making magnetite late again: Evidence for widespread magnetite growth by thermal decomposition of siderite in Hamersley banded iron formations. Precambrian Research 306: 64-93. https://doi.org/10.1016/j.preca mres.2017.12.017.

Rasmussen, B., D.B. Meier, B. Krapež, and J.R. Muhling. 2013. Iron silicate microgranules as precursor sediments to 2.5-billion-yearold banded iron formations. Geology 41(4): 435-438. https://doi. org/10.1130/G33828.1.

Rasmussen, B., B. Krapez, and D.B. Meier. 2014. Replacement origin for hematite in $2.5 \mathrm{Ga}$ banded iron formation: Evidence for postdepositional oxidation of iron-bearing minerals. Geological Society of America Bulletin 126(3-4): 438-446. https://doi.org/ 10.1130/B30944.1.

Rasmussen, B., B. Krapež, and J.R. Muhling. 2015a. Seafloor silicification and hardground development during deposition of $2.5 \mathrm{Ga}$ banded iron formations. Geology 43(3): 235-238. https://doi.org/ 10.1130/G36363.1

Rasmussen, B., B. Krapež, J.R. Muhling, and A. Suvorova. 2015b. Precipitation of iron silicate nanoparticles in early Precambrian oceans marks Earth's first iron age. Geology 43(4): 303-306. https://doi.org/10.1130/G36309.1.

Rasmussen, B., J.R. Muhling, A. Suvorova, and B. Krapež. 2017. Greenalite precipitation linked to the deposition of banded iron formations downslope from a late Archean carbonate platform. Precambrian Research 290: 49-62. https://doi.org/10.1016/j. precamres.2016.12.005.
Rasmussen, B., J.R. Muhling, and W.W. Fischer. 2019a. Evidence from laminated chert in banded iron formations for deposition by gravitational settling of iron-silicate muds. Geology 47(2): 167-170. https://doi.org/10.1130/G45560.1.

Rasmussen, B., J.R. Muhling, N.J. Tosca, and H. Tsikos. 2019b. Evidence for anoxic shallow oceans at $2.45 \mathrm{Ga}$ : Implications for the rise of oxygenic photosynthesis. Geology 47(7): 622-626. https:// doi.org/10.1130/G46162.1.

Rasmussen, B., J.R. Muhling, A. Suvorova, and W.W. Fischer. 2021. Apatite nanoparticles in 3.46-2.46 Ga iron formations: Evidence for phosphorus-rich hydrothermal plumes on early Earth. Geology. https://doi.org/10.1130/G48374.1.

Reddy, T.R., X. Zheng, E.E. Roden, B.L. Beard, and C.M. Johnson. 2016. Silicon isotope fractionation during microbial reduction of $\mathrm{Fe}(\mathrm{III})-\mathrm{Si}$ gels under Archean seawater conditions and implications for iron formation genesis. Geochimica et Cosmochimica Acta 190: 85-99. https://doi.org/10.1016/j.gca.2016.06.035.

Robbins, L.J., E.D. Swanner, S.V. Lalonde, M. Eickhoff, M.L. Paranich, C.T. Reinhard, C.L. Peacock, A. Kappler, and K.O. Konhauser. 2015. Limited Zn and Ni mobility during simulated iron formation diagenesis. Chemical Geology 402: 30-39. https://doi. org/10.1016/j.chemgeo.2015.02.037.

Robbins, L.J., S.V. Lalonde, N.J. Planavsky, C.A. Partin, C.T. Reinhard, B. Kendall, C. Scott, D.S. Hardisty, B.C. Gill, D.S. Alessi, et al. 2016. Trace elements at the intersection of marine biological and geochemical evolution. Earth-Science Reviews 163: 323-348. https://doi.org/10.1016/j.earscirev.2016.10.013.

Robbins, L.J., S.P. Funk, S.L. Flynn, T.J. Warchola, Z. Li, S.V. Lalonde, B.J. Rostron, A.B. Smith, N.J. Beukes, M.O. de Knock, et al. 2019. Hydrogeological constraints on the formation of Palaeoproterozoic banded iron formations. Nature Geoscience 17(12): 558-563. https://doi.org/10.1038/s41561-019-0372-0.

Roden, E.E., and J.W. Edmonds. 1997. Phosphate mobilization in iron-rich anaerobic sediments: Microbial Fe(III)oxide reduction versus iron-sulfide formation. Archiv für Hydrobiologie 193(3): 347-378. https://doi.org/10.1127/archiv-hydrobiol/139/1997/ 347.

Rye, R., and H.D. Holland. 1998. Paleosols and the evolution of atmospheric oxygen: A critical review. American Journal of Science 298: 621-672. https://doi.org/10.2475/ajs.298.8.621.

Saito, M.A., D.M. Sigman, and F.M.M. Morel. 2003. The bioinorganic chemistry of the ancient ocean: The co-evolution of cyanobacterial metal requirements and biogeochemical cycles at the Archean-Proterozoic boundary? Inorganica Chimica Acta 356: 308-318. https://doi.org/10.1016/S0020-1693(03)00442-0.

Schidlowski, M. 2001. Carbon isotopes as biogeochemical recorders of life over 3.8 Ga of Earth history: evolution of a concept. Precambrian Research 106(1-2): 117-134. https://doi.org/10.1016/ S0301-9268(00)00128-5.

Schirrmeister, B.E., P. Sanchez-Baracaldo, and D. Wacey. 2016. Cyanobacterial evolution during the Precambrian. International Journal of Astrobiology 15(3): 187-204. https://doi.org/10.1017/ S1473550415000579.

Schönheit, P., J. Moll, and R.K. Thauer. 1979. Nickel, cobalt, and molybdenum requirement for growth of Methanobacterium thermoautotrophicum. Archives of Microbiology 123(1): 105-107. https://doi.org/10.1007/BF00403508.

Schad, M., M. Halama, L.J. Robbins, T.J. Warchola, J. Tejada, R. Kirchhof, S.V. Lalonde, E.D. Swanner, N.J. Planavsky, H. Thorwarth, M. Mansor, K.O. Konhauser, and A. Kappler. 2021. Phosphate remobilization from banded iron formations during metamorphic mineral transformations. Chemical Geology 584: 120489. https://doi.org/10.1016/j.chemgeo.2021.120489.

Sergent, A.-S., F. Jorand, and K. Hanna. 2011. Effects of Si-bearing minerals on the nature of secondary iron mineral products from 
lepidocrocite bioreduction. Chemical Geology 289(1-2): 86-97. https://doi.org/10.1016/j.chemgeo.2011.07.016.

Shimizu, M., J. Zhou, C. Schröder, M. Obst, A. Kappler, and T. Borch. 2013. Dissimilatory reduction and transformation of ferrihydritehumic acid coprecipitates. Environmental Science \& Technology 47(23): 13375-13384. https://doi.org/10.1021/es402812j.

Siever, R. 1992. The silica cycle in the Precambrian. Geochimica et Cosmochimica Acta 56(8): 3265-3272. https://doi.org/10.1016/ 0016-7037(92)90303-Z.

Steinhoefel, G., F. von Blanckenburg, I. Horn, K.O. Konhauser, N.J. Beukes, and J. Gutzmer. 2010. Deciphering formation processes of banded iron formations from the Transvaal and the Hamersley successions by combined $\mathrm{Si}$ and $\mathrm{Fe}$ isotope analysis using UV femtosecond laser ablation. Geochimica et Cosmochimica Acta 74(9): 2677-2696. https://doi.org/10.1016/j.gca.2010.01.028.

Strous, M., and M.S.M. Jetten. 2004. Anaerobic oxidation of methane and ammonium. Annual Review of Microbiology 58: 99-117. https://doi.org/10.1146/annurev.micro.58.030603.123605.

Sun, S., K.O. Konhauser, A. Kappler, and Y.-L. Li. 2015. Primary hematite in Neoarchean to Paleoproterozoic oceans. Geological Society of America Bulletin 127(5-6): 850-861. https://doi.org/ 10.1130/B31122.1.

Sundman, A., T. Karlsson, S. Sjöberg, and P. Persson. 2016. Impact of iron-organic matter complexes on aqueous phosphate concentrations. Chemical Geology 426: 109-117. https://doi.org/10.1016/j. chemgeo.2016.02.008.

Swanner, E.D., A.M. Mloszewska, O.A. Cirpa, R. Schoenberg, K.O. Konhauser, and A. Kappler. 2015a. Modulation of oxygen production in Archean oceans by episodes of Fe(II) toxicity. Nature Geoscience 8(2): 126-130. https://doi.org/10.1038/ngeo2327.

Swanner, E.D., W. Wu, L. Hao, M.L. Wüstner, M. Obst, D.M. Moran, M.R. McIlvin, M.A. Saito, and A. Kappler. 2015b. Physiology, $\mathrm{Fe}(\mathrm{II})$ oxidation, and Fe mineral formation by a marine planktonic cyanobacterium grown under ferruginous conditions. Frontiers in Earth Science. https://doi.org/10.3389/feart.2015.00060.

Swanner, E.D., W. Wu, L. Hao, M.L. Wüstner, M. Obst, D.M. Moran, M.R. McIlvin, M.A. Saito, and A. Kappler. 2015c. Physiology, $\mathrm{Fe}(\mathrm{II})$ oxidation, and Fe mineral formation by a marine planktonic cyanobacterium growth under ferruginous conditions. Frontiers in Earth Science 3: 60.

Teixeira, N.L., F.A. Caxito, C.A. Rosière, E. Pecoits, L. Vieira, R. Frei, A.N. Sial, and F. Poitrasson. 2017. Trace elements and isotope geochemistry $(\mathrm{C}, \mathrm{O}, \mathrm{Fe}, \mathrm{Cr})$ of the Cauê iron formation, Quadrilátero Ferrífero, Brazil: Evidence for widespread microbial dissimilatory iron reduction at the Archean/Paleoproterozoic transition. Precambrian Research 298: 39-55. https://doi.org/ 10.1016/j.precamres.2017.05.009.

ThomasArrigo, L.K., J.M. Byrne, A. Kappler, and R. Kretzschmar. 2018. Impact of Organic Matter on Iron(II)-Catalyzed Mineral Transformations in Ferrihydrite-Organic Matter Coprecipitates. Environmental Science \& Technology 52(21): 12316-12326. https://doi.org/10.1021/acs.est.8b03206.

Thompson, K.J., P.A. Kenward, K.W. Bauer, T. Warchola, T. Gauger, R. Martinez, R.L. Simister, C.C. Michiels, M. Llirós, C.T. Reinhard, et al. 2019. Photoferrotrophy, deposition of banded iron formations, and methane production in Archean oceans. Science Advances 5(11): eaav2869. https://doi.org/10.1126/sciadv.aav28 69.

Tice, M.M., and D.R. Lowe. 2004. Photosynthetic microbial mats in the 3,416-Myr-old ocean. Nature 431: 549-552. https://doi.org/ 10.1038 /nature 02888 .

Tosca, N.J., S. Guggenheim, and P.K. Pufahl. 2016. An authigenic origin for Precambrian greenalite: Implications for iron formation and the chemistry of ancient seawater. Bulletin 128(3-4): 511-530. https://doi.org/10.1130/B31339.1.
Trendall, A.F. 2002. The significance of iron-formation in the Precambrian stratigraphic record. Special Publications International Association of Sedimentologists 33: 33-66. https://doi.org/10. 1002/9781444304312.ch3.

Trendall, A.F., and J.G. Blockley. 1970. The iron formations of the Precambrian Hamersley Group, Western Australia with special reference to the associated crocidolite. Geological Survey of Western Australia 119: 336.

Tyrrell, T. 1999. The relative influences of nitrogen and phosphorus on oceanic primary production. Nature 400(6744): 525-531. https:// doi.org/10.1038/22941.

Kranendonk, M.J. van. 2006. Volcanic degassing, hydrothermal circulation and the flourishing of early life on Earth: A review of the evidence from c. 3490-3240 Ma rocks of the Pilbara Supergroup, Pilbara Craton, Western Australia. Earth-Science Reviews 74(34): 197-240. https://doi.org/10.1016/j.earscirev.2005.09.005.

Wacey, D., N. McLoughlin, O.R. Green, J. Parnell, C.A. Stoakes, and M.D. Brasier. 2006. The 3.4 billion-year-old Strelley Pool Sandstone: a new window into early life on Earth. International Journal of Astrobiology 5(4): 333-342. https://doi.org/10.1017/ S1473550406003466.

Walker, J.C.G. 1984. Suboxic diagenesis in banded iron formations. Nature 309(5966): 340-342. https://doi.org/10.1038/309340a0.

Weber, K.A., J. Pollock, K.A. Cole, S.M. O'Connor, L.A. Achenbach, and J.D. Coates. 2006. Anaerobic nitrate-dependent iron(II) biooxidation by a novel lithoautotrophic betaproteobacterium, strain 2002. Applied and Environmental Microbiology 72(1): 686-694. https://doi.org/10.1128/AEM.72.1.686-694.2006.

Widdel, F., S. Schnell, S. Helsing, A. Ehrenreich, B. Assmus, and B. Schink. 1993. Ferrous iron oxidation by anoxygenic phototrophic bacteria. Nature 362: 834-836. https://doi.org/10.1038/ $362834 \mathrm{a} 0$.

Woese, C.R. 1987. Bacterial Evolution. Microbiological Reviews 51(2): 221-271.

Wu, L., E.M. Percak-Dennett, B.L. Beard, E.E. Roden, and C.M. Johnson. 2012. Stable iron isotope fractionation between aqueous $\mathrm{Fe}(\mathrm{II})$ and model Archean ocean $\mathrm{Fe}-\mathrm{Si}$ coprecipitates and implications for iron isotope variations in the ancient rock record. Geochimica et Cosmochimica Acta 84: 14-28. https://doi.org/10. 1016/j.gca.2012.01.007.

Wu, W., E.D. Swanner, L. Hao, F. Zeitvogel, M. Obst, Y. Pan, and A. Kappler. 2014. Characterization of the physiology and cell-mineral interactions of the marine anoxygenic phototrophic Fe(II) oxidizer Rhodovulum iodosum-implications for Precambrian $\mathrm{Fe}(\mathrm{II})$ oxidation. FEMS Microbiology Ecology 88(3): 503-515. https://doi.org/10.1111/1574-6941.12315.

Xiong, J. 2006. Photosynthesis: What color was its origin? Biology 7(245): 1-5. https://doi.org/10.1186/gb-2006-7-12-245.

Yamaguchi, K.E., C.M. Johnson, B.L. Beard, and H. Ohmoto. 2005. Biogeochemical cycling of iron in the Archean-Paleoproterozoic Earth: Constraints from iron isotope variations in sedimentary rocks from the Kaapvaal and Pilbara Cratons. Chemical Geology 218(1-2): 135-169. https://doi.org/10.1016/j.chemgeo.2005.01. 020.

Yan, J., T. Jiang, Y. Yao, S. Lu, Q. Wang, and S. Wei. 2016. Preliminary investigation of phosphorus adsorption onto two types of iron oxide-organic matter complexes. Journal of Environmental Sciences 42: 152-162. https://doi.org/10.1016/j.jes.2015.08.008.

Zachara, J.M., R.K. Kukkadapu, J.K. Fredrickson, Y.A. Gorby, and S.C. Smith. 2002. Biomineralization of poory crystalline Fe(III) oxides by dissimilatory metal reducing bacteria (DMRB). Geomicrobiology Journal 19(2): 179-207. https://doi.org/10.1080/ 01490450252864271.

Zahnle, K., M. Claire, and D.C. Catling. 2006. The loss of massindependent fractionation in sulfur due to a Palaeoproterozoic 
collapse of atmospheric methane. Geobiology 4(4): 271-283. https://doi.org/10.1111/j.1472-4669.2006.00085.x.

Zegeye, A., S. Bonneville, L.G. Benning, A. Sturm, D.A. Fowle, C. Jones, D.E. Canfield, C. Ruby, L.C. MacLean, S. Nomosatryo, et al. 2012. Green rust formation controls nutrient availability in a ferruginous water column. Geology 40(7): 599-602. https:// doi.org/10.1130/G32959.1.

Zerkle, A.L. 2005. Biogeochemical signatures through time as inferred from whole microbial genomes. American Journal of Science 305(6-8): 467-502. https://doi.org/10.2475/ajs.305.6-8.467.
Zhou, Z., D.E. Latta, N. Noor, A. Thompson, T. Borch, and M.M. Scherer. 2018. Fe(II)-Catalyzed Transformation of Organic Matter-Ferrihydrite Coprecipitates: A Closer Look Using Fe Isotopes. Environmental Science \& Technology 52(19): 1114211150. https://doi.org/10.1021/acs.est.8b03407. 